NATÁLIA MARTINS BITTAR-RODRIGUES

\title{
DISTRIBUIÇÃO DA GHRELINA E DE SEU RECEPTOR NA MUCOSA GÁSTRICA DE RATOS SUBMETIDOS AO DESMAME PRECOCE: EFEITOS SOBRE A PROLIFERAÇÃO CELULAR EPITELIAL
}

Dissertação apresentada ao Programa de PósGraduação em Biologia Celular e Tecidual do Instituto de Ciências Biomédicas da Universidade de São Paulo, para obtenção do Título de Mestre em Ciências. 


\section{DISTRIBUIÇÃO DA GHRELINA E DE SEU RECEPTOR NA MUCOSA GÁSTRICA DE RATOS SUBMETIDOS AO DESMAME PRECOCE: EFEITOS SOBRE A PROLIFERAÇÃO CELULAR EPITELIAL}

Dissertação apresentada ao Programa de PósGraduação em Biologia Celular e Tecidual do Instituto de Ciências Biomédicas da Universidade de São Paulo, para obtenção do Título de Mestre em Ciências.

Área de concentração: Biologia Celular e Tecidual.

Orientadora: Prof ${ }^{\mathrm{a}}$. Dr ${ }^{\mathrm{a}}$. Patrícia Gama.

Versão original. 
DADOS DE CATALOGAÇÃO NA PUBLICAÇÃO (CIP)

Serviço de Biblioteca e Informação Biomédica do

Instituto de Ciências Biomédicas da Universidade de São Paulo

reprodução não autorizada pelo autor

Bittar-Rodrigues, Natália Martins.

Distribuição da ghrelina e de seu receptor na mucosa gástrica de ratos submetidos ao desmame precoce: efeitos sobre a proliferação celular epitelial / Natália Martins Bittar-Rodrigues. -- São Paulo, 2012.

Orientador: Profa. Dra. Patrícia Gama.

Dissertação (Mestrado) - Universidade de São Paulo. Instituto de Ciências Biomédicas. Departamento de Biologia Celular e do Desenvolvimento. Área de concentração: Biologia Celular e Tecidual. Linha de pesquisa: Biologia dos epitélios digestivos.

Versão do título para o inglês: Ghrelin and growth hormone secretagogue receptor distribution in the gastric mucosa of early weaned rats: effects on epithelial cell proliferation.

$\begin{array}{llll}\text { 1. Estômago } & \text { 2. Ghrelina } & \text { 3. Amamentação } & 4 \text {. Receptor secretagogo }\end{array}$ do hormônio de crescimento 5. Desmame precoce efeitos sobre a proliferação celular epitelial 6. Desenvolvimento pós-natal I. Gama, Profa. Dra. Patrícia II. Universidade de São Paulo. Instituto de Ciências Biomédicas. Programa de Pós-Graduação em Biologia Celular e Tecidual III. Título. 
Candidato(a):

Título da Dissertação:

Orientador(a):
Natália Martins Bittar-Rodrigues.

Distribuição da ghrelina e de seu receptor na mucosa gástrica de ratos submetidos ao desmame precoce: efeitos sobre a proliferação celular epitelial.

Profa. Dra. Patrícia Gama.

A Comissão Julgadora dos trabalhos de Defesa da Dissertação de Mestrado, em sessão pública realizada a .

( ) Aprovado(a) ( ) Reprovado(a)

Examinador(a): Assinatura:

Nome:

Instituição:

Examinador(a): Assinatura:

Nome:

Instituição:

Presidente:

Assinatura:

Nome:

Instituição: 


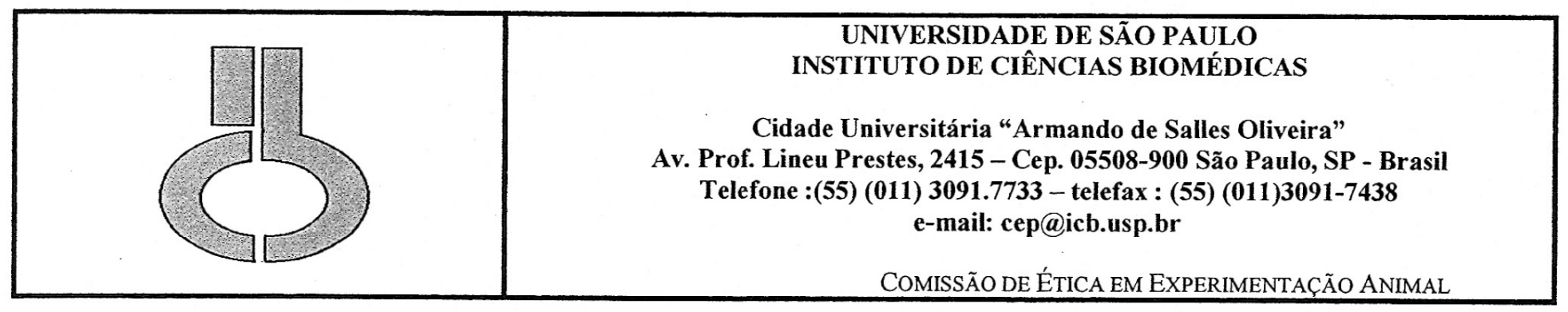

Decl. CEEA.045.09

\section{E C L A R A Ç Ã O}

Em adendo ao Certificado 86/08/CEEA datado de 18.09.08, por solicitação da Profa.Dra. Patrícia Gama, responsável pela linha de Pesquisa, autorizo a inclusão da aluna Natália Martins Bittar Rodrigues ao projeto de pesquisa "Mecanismo de regulação do crescimento gástrico: interação entre padrão alimentar, corticosterona e fatores de crescimento", uma vez que se trata de utilização da mesma espécie animal e de métodos experimentais similares ao referido certificado.

São Paulo, 05 de agosto de 2009.

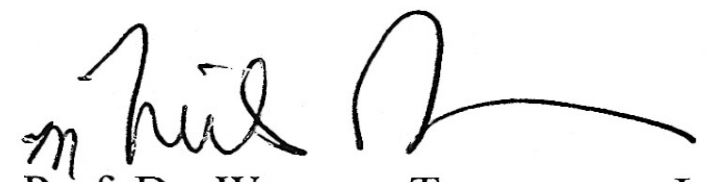

Prof. Dr. Wothan TAVARES DE LIMA

Coordenador -CEEA- ICB/USP 


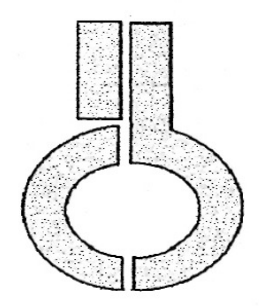

UNIVERSIDADE DE SÃO PAULO
INSTITUTO DE CIÊNCIAS BIOMÉDICAS

Cidade Universitária "Armando de Salles Oliveira"

Av. Prof. Lineu Prestes, 2415 - CEP. 05508-000 São Paulo, SP - Brașil

Telefone :(55) (011) 3091.7733 - telefax : (55) (011) 3091.7438

e-mail: ceponch.asp.br

\section{Certificado}

Certificamos que o protocolo registrado sob $n^{\circ} 86$ nas fls. 60 do livro 02 para uso de animais em experimentação, sob a responsabilidade de Patrícia Gama, Coordenador(a) da Linha de pesquisa "Mecanismo de regulação do crescimento gástrico: interação entre padrão alimentar, corticosterona $e$ fatores de crescimento" do qual participou(aram) o(s) alunos Priscila Moreira Figueiredo, Marco Aurélio Fauni Curi, Daniela Ogias, Luciana Harumi Osaka está de acordo com os Princípios Éticos de Experimentação Animal adotado pelo Colégio Brasileiro de Experimentação Animal (COBEA) e foi aprovado pela COMISSÃO DE ÉTICA EM EXPERIMENTAÇÃO ANIMAL (CEEA) em 18.09.08, com validade de 3 anos.

São Paulo, 19 de setembro de 2008.

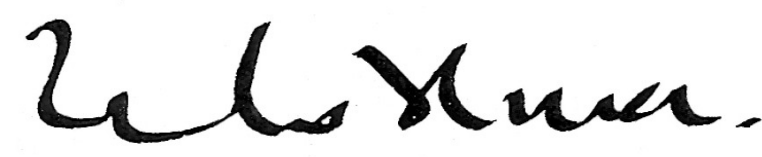

Prof. Dr. WOTHAN TAVARES DE LIMA Coordenador CEEA - ICB/USP

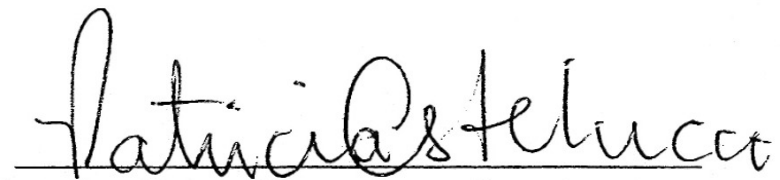

Profa. Dra. PATRÍCIA CASTELUCCI Secretária CEEA - ICB/USP 


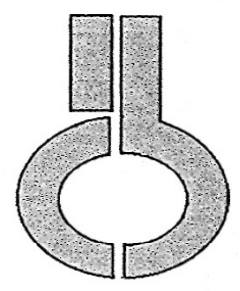

UNIVERSIDADE DE SÃO PAULO

INSTITUTO DE CIÊNCIAS BIOMÉDICAS

Cidade Universitária "Armando de Salles Oliveira"

Av. Prof. Lineu Prestes, 2415 - CEP. 05508-000 São Paulo, SP Brasil

Telefone :(55) (011) 3091.7733 - e-mail: cep@icb.usp.br

\section{CerTIFICADO}

Certificamos que o protocolo registrado sob $n^{\circ} \mathbf{8 0}$ nas fls. 105 do livro 02 para uso de animais em experimentação, sob a responsabilidade do Prof(a) Dr(a)) Patrícia Gama, Coordenador(a) da Linha de pesquisa "Papel de hormônios e fatores de crescimento na mucosa gástrica de ratos submetidos ao desmame precoce" do qual participam o(s) Camila Kamla Martinatti, Heloisa Ghizoni, Juliana Guimaraes Zulian Maria Gabriela Soares Lima, Nataália Martins Bittar Rodrigues e as pesquisadores Marinilce Fagundes dos Santos, Daniela Ogias, Luciana Harumi Osaki, está de acordo com os Princípios Éticos de Experimentação Animal adotado pela Sociedade Brasileira de Ciência de Animais de Laboratório (SBCAL) e foi aprovado pela COMISSÃO DE ÉTICA NO USO DE ANIMAIS (CEUA) em 05.07.2011, com validade de 3 anos.

'São Paulo, 12 de julho de 2011.

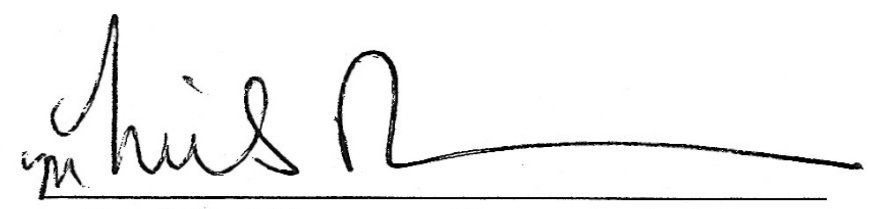

Prof.Dr.WOTHAN TAVARES DE LIMA

Coordenador

CEUA - ICB/USP

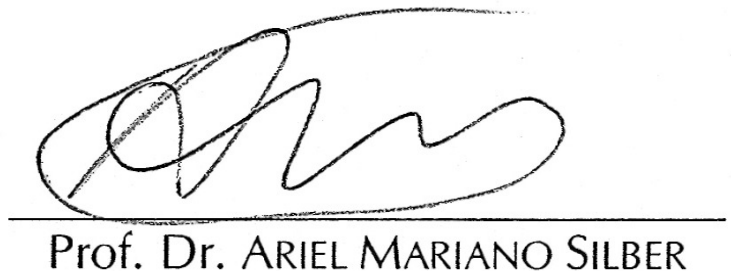

Secretário

CEUA - ICB/USP 
Dedico este trabalho às pessoas que sempre acreditaram em mim, me incentivaram, me encorajaram e me confortaram em todos os bons e maus momentos, meus pais, Jorge e Irene, minha irmã Laura e meu marido Laudenir Junior. Poder sempre contar com o carinho e o amparo de vocês e com a sabedoria de suas palavras foi o que me permitiu iniciar, percorrer e concluir essa etapa. Obrigada por, mais uma vez, me guiarem pelos caminhos da vida. Vocês são os responsáveis por essa conquista! Amo vocês... Muito e sempre. 


\section{AGRADECIMENTOS ESPECIAIS}

À querida Prof $^{\mathrm{a}}$. Dr ${ }^{\mathrm{a}}$. Patrícia Gama, minha orientadora, que me acolheu em seu laboratório e confiou em mim. Você é um exemplo a ser seguido, como docente e pesquisadora competente e dedicada. Contudo, sua participação nessa trajetória vai muito além do conhecimento técnico, pois sem a sua compreensão, seu carinho, sua amizade e as inúmeras horas dedicadas a me ouvir e me aconselhar, certamente as barreiras para a conclusão dessa jornada seriam imensamente maiores. Sem o seu voto de confiança, nada do que se encontra nessas páginas seria possível... Você sempre terá a minha gratidão. 
Ao meu querido avô, Nelson, por seu apoio e incentivo nessa caminhada. Obrigada por estar sempre presente, mesmo que de longe, comemorando os momentos alegres e consolando nos momentos difíceis. 


\section{AGRADECIMENTOS}

A Deus, por permitir essa conquista.

Aos meus familiares, pelo apoio e incentivo durante essa jornada.

À Prof ${ }^{a}$. Dra . Eliana Parisi Alvares, que me conduziu nos meus primeiros passos durante a iniciação científica e transmitiu valiosos ensinamentos.

Às $\operatorname{Prof}^{\mathrm{a}}{ }^{\mathrm{a}}$. Dr ${ }^{\mathrm{a}}$. Alison Colquhoun, Dr ${ }^{\mathrm{a}}$. Vanessa Morais Freitas e à $\operatorname{Dr}^{\mathrm{a}}$. Cilene Rebouças de Lima pela importante contribuição com observações e sugestões feitas durante o exame de qualificação.

Às Prof ${ }^{\text {as }}$. Dr ${ }^{\mathrm{a}}$. Vanessa Morais Freitas, Dr ${ }^{\mathrm{a}}$. Nathalie Cella, Dr ${ }^{\mathrm{a}}$. Marilene Hohmuth Lopes e ao Prof. Dr. Fábio Siviero, que cederam gentilmente as chaves de seus laboratórios para que eu pudesse realizar meus experimentos em seus equipamentos.

Às Prof ${ }^{\text {as }}$. Dr ${ }^{\text {a }}$. Estela M. A. F. Bevilacqua e Dra . Gláucia Maria Machado-Santelli por permitirem o livre acesso aos seus laboratórios, disponibilizarem seus equipamentos e por estarem sempre prontas a cooperar.

À Prof ${ }^{a}$. Dr ${ }^{a}$. Maria Inês Borella, que sempre me recebeu com um sorriso e disposição em ajudar.

À Luciana Osaki, pela amizade e pelas longas conversas que auxiliaram, esclareceram e confortaram em tantos momentos. Pela sua constante disposição em ensinar e ajudar, por diversas vezes priorizar as minhas dúvidas e meus experimentos frente aos seus compromissos. Muito obrigada por toda a atenção e carinho que dedicou a mim.

À Daniela Ogias, que me ajudou em diversos momentos e de tantas maneiras. Que, em meio às idas e vindas para a nossa cidade, me escutou, me consolou e me aconselhou. Obrigada pelo carinho, pela confiança e pela amizade. 
À Heloisa Ghizoni, que sempre me ofereceu um abraço apertado e disponibilizou seu tempo, seus ouvidos e seu apoio nos momentos alegres e, principalmente, nos momentos difíceis desta caminhada. Obrigada por estar sempre por perto e ao meu lado, por rir e chorar comigo.

À Juliana Zulian, companheira e amiga. Obrigada pelos inúmeros ensinamentos técnicos, pela ajuda em tantos procedimentos e, acima de tudo, pelo incentivo, pelos conselhos e pela amizade que dedicou a mim.

À Priscila Figueiredo que nunca poupou esforços para ajudar, que me acompanhou, me ensinou e sempre teve um sorriso contagiante, que alegra a todos, e um abraço confortante e carinhoso que me amparou em tantos momentos. Você faz muita falta por aqui!

À Camila Martinatti, pela generosidade, pelo carinho e pela amizade.

À Ariane Kasai, que iniciou os trabalhos com a ghrelina no laboratório e foi companheira de conversas e discussões sobre o tema. Muito obrigada pela amizade e por toda a ajuda.

À Ana Paula Fiore, a mais nova integrante do grupo, pelos ensinamentos, pela ajuda e pela amizade.

Ao Cruz Alberto Mendoza Rigonati (Junior) que atendeu prontamente aos meus inúmeros pedidos de cortes de lâminas e ofereceu sua ajuda e suporte técnico, indispensáveis para a concretização deste trabalho.

A todos que cruzaram meu caminho dentro do laboratório, desde a minha iniciação científica, e contribuíram para este trabalho, tanto pela amizade, quanto pelo auxílio técnico: Luciana Jordão, Eunice, Jean, Ana Luíza, Gabriel, Maria Helena e Larissa.

Ao Adam Martens pela disposição em ajudar, pela amizade e pelas boas risadas proporcionadas durante os momentos de descontração. 
À Fabiana Cruz, que enfrentou comigo o desafio de gravarmos uma aula para o curso à distância organizado pela Prof ${ }^{\mathrm{a}}$. Dra . Patrícia Gama.

Aos meus colegas da pós-graduação, com quem tive a oportunidade de aprender e compartilhar conquistas e preocupações.

Às minhas queridas amigas Bianca Bitencourt e Carina Lima, que estão sempre por perto, incentivando e ajudando a enfrentar os inúmeros obstáculos que a vida oferece.

Às secretárias do departamento, Ana Lúcia, Celiana, Eloise e Regina, que se mostraram atenciosas e me atenderam prontamente nos momentos em que precisei.

Aos funcionários do biotério, Braz, Cláudio e Fernando, que tratam dos nossos animais com muito cuidado e dedicação. Obrigada por toda a ajuda!

À equipe da biblioteca do Instituto de Ciências Biomédicas, que sempre me atendeu com simpatia, cordialidade e presteza.

Ao Conselho Nacional de Desenvolvimento Científico e Tecnológico $(\mathrm{CNPq})$ e à Fundação de Amparo à Pesquisa do Estado de São Paulo (FAPESP) pelo suporte financeiro, essencial para a realização deste trabalho. 
"As we acquire more knowledge, things do not become more comprehensible, but more mysterious". Albert Schweitzer 


\section{RESUMO}

Bittar-Rodrigues NM. Distribuição da ghrelina e de seu receptor na mucosa gástrica de ratos submetidos ao desmame precoce: efeitos sobre a proliferação celular epitelial. [dissertação (Mestrado em Biologia Celular e Tecidual)]. São Paulo: Instituto de Ciências Biomédicas, Universidade de São Paulo; 2012.

O leite materno, fonte exclusiva de nutrientes durante a lactação, contém hormônios e fatores de crescimento capazes de estimular a maturação, o desenvolvimento funcional e o crescimento do trato gastrintestinal. O desmame é a transição do aleitamento para a ingestão de alimento sólido e representa um período importante para o desenvolvimento do animal. $\mathrm{O}$ desmame precoce, caracterizado pela interrupção abrupta do aleitamento, provoca uma série de alterações na mucosa do estômago, órgão que é o principal local de síntese da ghrelina, um hormônio relacionado com a ingestão de alimentos e metabolismo. No presente trabalho, investigamos a distribuição de ghrelina e de seu receptor (GHS-R) na mucosa gástrica de ratos durante a terceira semana de vida pós-natal e avaliamos o efeito do desmame precoce sobre estas moléculas. Estudamos também a participação da ghrelina no controle da proliferação celular do epitélio gástrico, e para tanto utilizamos a administração de um antagonista. Por meio de imuno-histoquímica, detectamos o aumento do número de células imunomarcadas para ghrelina nos animais desmamados precocemente. Com o uso da técnica de RT-PCR, observamos que a expressão de $G H S$ - $R$ não foi alterada pela mudança da dieta e, após a realização de Western blot confirmamos que a concentração do receptor na mucosa gástrica também não foi modificada. O uso do antagonista [D-Lys-3]-GHRP-6 resultou na diminuição do índice de síntese de DNA no epitélio gástrico, avaliado por meio de imunohistoquímica para BrdU. Concluímos que a ghrelina e o GHS-R estão distribuídos no estômago durante a terceira semana de vida pós-natal e que o desmame precoce aumenta os níveis de ghrelina no epitélio gástrico, sem comprometer seu receptor. Por fim, sugerimos que esta modulação pode estar envolvida no controle da proliferação celular que é fundamental para o desenvolvimento do estômago.

Palavras-chave: Estômago. Ghrelina. Amamentação. Receptor secretagogo do hormônio de crescimento. Desmame precoce. Desenvolvimento pós-natal. 


\begin{abstract}
Bittar-Rodrigues NM. Ghrelin and growth hormone secretagogue receptor distribution in the gastric mucosa of early weaned rats: effects on epithelial cell proliferation. [Masters thesis (Cell and Tissue Biology)]. São Paulo: Instituto de Ciências Biomédicas, Universidade de São Paulo; 2012.

Maternal milk is the exclusive source of nutrients during lactation and carries hormones and growth factors that promote maturation, functional development and growth of the gastrointestinal tract. Weaning marks the transition from suckling to solid food intake and it is important for appropriate postnatal development. Early weaning is the abrupt interruption of suckling, and induces several effects in stomach, which is the major site of ghrelin synthesis, a hormone that induces food intake and is related to metabolism control. In the present study, we investigated the distribution of ghrelin and growth hormone secretagogue receptor (GHSR) in the rat gastric mucosa during the third postnatal week, and evaluated the effects of early weaning on these molecules. In addition, we studied whether ghrelin is part of cell proliferation control in gastric epithelium, and to that we used an antagonist. By using immunohistochemistry, we detected an increase of ghrelin immunolabelled cells in animals submitted to early weaning. After RT-PCR, we observed that $G H S-R$ expression was not altered by dietary change and this result was confirmed through Western blot, whereby we observed receptor levels. The antagonist [D-Lys-3]-GHRP-6 reduced DNA synthesis index, as determined by BrdU incorporation followed by immunohistochemistry. We concluded that ghrelin and GHS-R are distributed in the gastric mucosa during the third postnatal week and that early weaning increases hormone levels in the gastric epithelium, without changing its receptor. We can suggest that such modulation might be involved in the control of cell proliferation, which is essential for stomach development.
\end{abstract}

Keywords: Stomach. Ghrelin. Suckling. Growth hormone secretagogue receptor. Early weaning. Postnatal development. 


\section{LISTA DE ILUSTRAÇÕES}

Figura 1 - Sequência de aminoácidos que compõem a ghrelina em humanos e ratos............28

Figura 2 - Modificação pós-traducional da pró-ghrelina...................................................... 31

Figura 3 - Liberação de GH pela hipófise por meio dos receptores GHRH-R e GHS-R. .......33

Figura 4 - Esquema de procedimentos e coletas............................................................ 48

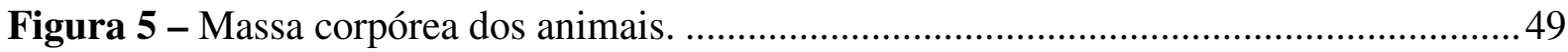

Figura 6 - Efeito do desmame precoce sobre a ghrelina gástrica. ......................................52

Figura 7 - Efeito do desmame precoce sobre a expressão gástrica do receptor GHS-R.........54

Figura 8 - Efeito da ghrelina sobre a proliferação da mucosa gástrica..................................56 


\section{LISTA DE TABELAS}

Tabela 1 - Caracterização dos experimentos com [D-Lys-3]-GHRP-6 39

Tabela 2 - Sequência dos oligonucleotídeos iniciadores utilizados para a realização de RTPCR. 45

Tabela 3 - Parâmetros relativos ao fracionamento de proteínas para o estudo de ghrelina, GHS-R1a e GHS-R 47

Tabela 4 - Anticorpos primários utilizados para immunoblot. 47 


\section{LISTA DE ABREVIATURAS E SIGLAS}

AIDS

AGRP

AMPc

ANOVA

BrdU

BSA

$\mathrm{C}$

$\left[\mathrm{Ca}^{2+}\right] \mathrm{i}$

cDNA

C-terminal

$\mathrm{CoA}$

$\mathrm{DAB}$

DNA

DEPC

dNTP

DP

DPA

$\mathrm{DPA}-[5]$

DPA - [10]

DTT

ECL

EGFR

EDTA

FSH

$\mathrm{GH}$

GHRH

GHRH-R

GHRP-6

GHS

GHS-R

GOAT

GPCR
Síndrome da imunodeficiência adquirida

"Agouti-related peptide"

Monofosfato cíclico de adenosina

Análise de variância

Bromodeoxiuridina

"Bovine serum albumine"

Controle

Concentração intracelular do íon cálcio

Ácido desoxirribonucleico complementar

Extremidade carboxi-terminal da cadeia peptídica

Coenzima A

3,3'tetra-hidrocloreto de diaminobenzidina

Ácido desoxirribonucleico

Dietilpirocarbonato

"Deoxynucleotide triphosphate"

Desmame precoce

Desmame precoce tratado com antagonista

DPA - 2 doses de $5 \mu \mathrm{g} / \mathrm{g}$ de massa corpórea cada

DPA - 2 doses de $10 \mu \mathrm{g} / \mathrm{g}$ de massa corpórea cada

"Dithiothreitol"

"Enterochromaffin-like cells"

Receptor do Fator de crescimento epidermal

Ácido etilenodiaminotetracético

Hormônio folículo-estimulante

Hormônio de crescimento

Hormônio liberador do hormônio de crescimento

Receptor do hormônio liberador do hormônio de crescimento

"Growth hormone-releasing peptide-6"

Secretagogo do hormônio de crescimento

Receptor secretagogo de hormônio de crescimento

"Ghrelin $O$-acyltransferase"

Receptor acoplado à proteína $\mathrm{G}$ 
HE

i.c.v.

IOD

i.p.

$\mathrm{IP}_{3}$

IS

LH

MBOAT

$\mathrm{N}$-terminal

NPY

ODC

OMS

PBS

PBS-BSA

PC $1 / 3$

PRL

PMSF

RE

RIPA

RNA

RNAm

RT-PCR

s.c.

SDS

TA

TAE

TBS

TGF

TSH

TTBS

$\mathrm{T} \beta \mathrm{R}$
Hematoxilina e eosina

Intracérebroventricular

Densidade óptica integrada

Intraperitoneal

Inositol 1, 4, 5-trifosfato

Índice de síntese de DNA

Hormônio luteinizante

"Membrane bound $O$-acyltransferase"

Extremidade amino-terminal da cadeia peptídica

Neuropeptídeo Y

Ornitina descarboxilase

Organização Mundial de Saúde

Tampão fosfato salina

BSA $0,1 \%$ em PBS $0,05 \mathrm{M}$

Pró-hormônio convertase 1/3

Prolactina

Fluoreto de fenilmetilsulfonil

Retículo endoplasmático

"Radio-immunoprecipitation assay buffer"

Ácido ribonucleico

Ácido ribonucleico mensageiro

Reação em cadeia da polimerase com transcriptase reversa

Subcutânea

"Sodium dodecyl sulfate"

Temperatura ambiente

Tris acetato $40 \mathrm{mM}$ - EDTA $1 \mathrm{mM}$

Solução salina tamponada com Tris

Fator de crescimento transformante

Hormônio estimulante da tireoide

Tween 20 0,1\% em TBS 0,02 M

Receptor do Fator de crescimento transformante $\beta$ 


\section{LISTA DE SÍMBOLOS}

\section{AMINOÁCIDOS}

Arginina

\section{BASES NITROGENADAS DOS NUCLEOTÍDEOS}

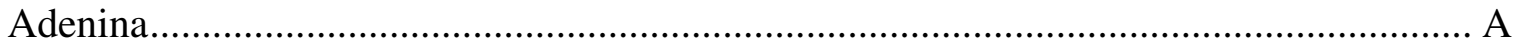

Citosina

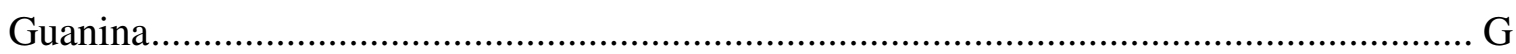

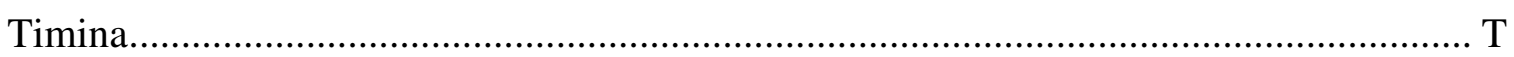




\section{SUMÁRIO}

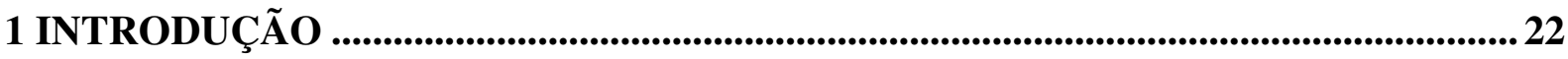

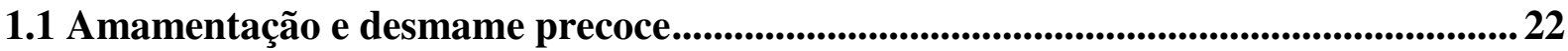

1.2 Estômago ........................................................................................................................................................... 25

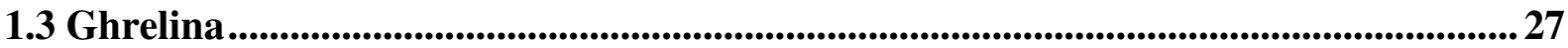

1.4 Receptor GHS-R .................................................................................................................................... 32

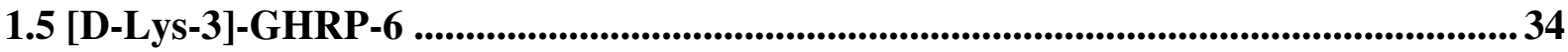

2 JUSTIFICATIVA ........................................................................................................................ 36

3 OBJETIVOS …............................................................................................................................3 37

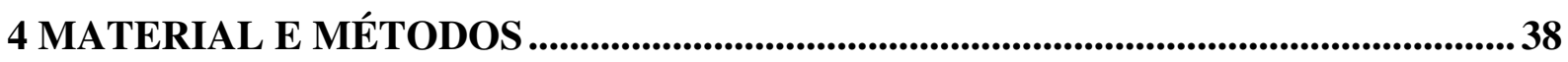

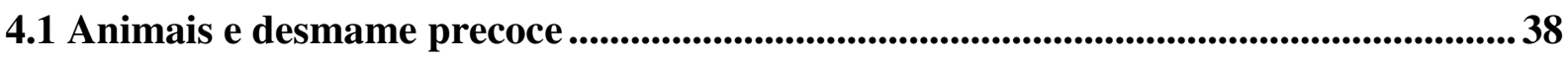

4.2 Tratamento com [D-Lys-3]-GHRP-6 .................................................................. 38

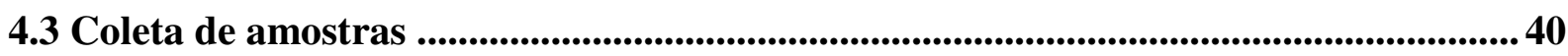

4.3.1 Coletas para análises morfológicas e imuno-histoquímica ....................................... 40

4.3.2 Coletas para RT-PCR e Western blot......................................................................... 40

4.4 Imuno-histoquímica e quantificação das células imunomarcadas.............................. 41

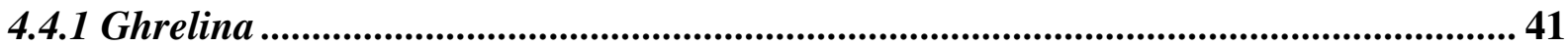

4.4.2 BrdU - Determinação do Índice de síntese de DNA (IS)......................................... 42

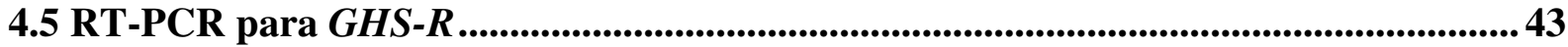

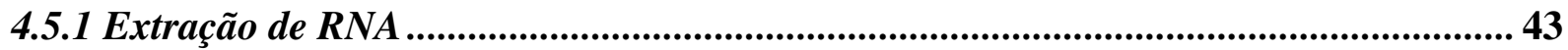

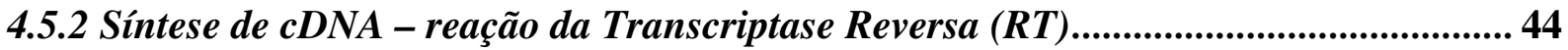

4.5.3 Amplificação do DNA - Reação em cadeia da polimerase (PCR).................................. 44

4.6 Western blot ........................................................................................................................................... 45

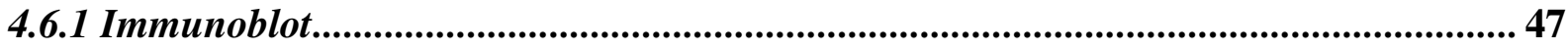

4.7 Análise estatística............................................................................................................................. 48

4.8 Esquema dos procedimentos ................................................................................................... 48

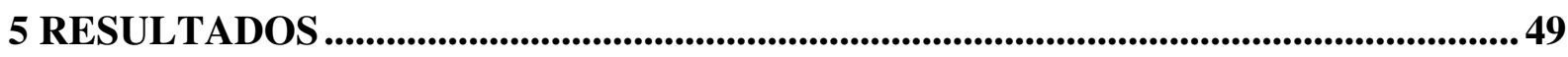

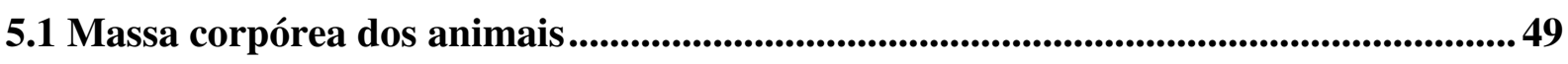

5.2 Efeito do desmame precoce sobre a ghrelina gástrica.......................................................50

5.3 Efeito do desmame precoce sobre a expressão gástrica do receptor GHS-R..............53

5.4 Efeito da ghrelina sobre a proliferação da mucosa gástrica.............................................55

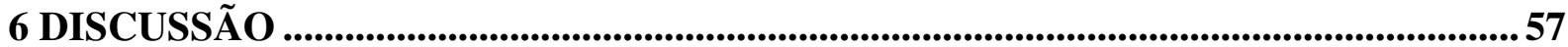

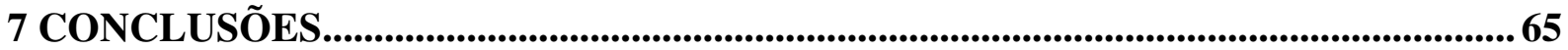

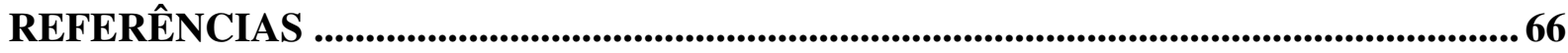




\section{INTRODUÇÃO}

\subsection{Amamentação e desmame precoce}

A Organização Mundial de Saúde (OMS) (World Health Organization, 2002) preconiza que "a amamentação é uma maneira inigualável de fornecer alimento ideal para o crescimento e o desenvolvimento saudáveis das crianças [...]”.

A amamentação exclusiva até os seis meses de idade assegura benefícios tanto à criança, quanto à mãe, sendo o principal benefício à saúde das crianças observado em curto prazo: a redução da mortalidade e da morbidade por doenças infecciosas. Assim, a OMS recomenda o aleitamento materno exclusivo até os seis primeiros meses de idade, quando se inicia a introdução da alimentação complementar, porém sem a suspensão do aleitamento por completo, que deve prosseguir até dois anos de idade ou mais (Horta et al., 2007; WHO, 2001).

A percepção de que a exposição a determinadas condições nos primeiros anos de vida, incluindo-se o padrão nutricional da criança, pode gerar efeitos observados na vida adulta, deu origem à ideia de "programação", ou seja, "[...] um processo no qual um estímulo aplicado em um período crítico ou sensível do desenvolvimento, resulta em um efeito de longo prazo ou permanente na estrutura ou função do organismo [...]” (Horta et al., 2007).

Em um estudo de meta-análise, Harder et al. (2005) concluíram que há uma associação dose-dependente entre o prolongamento do período de lactação e a diminuição do risco para obesidade na vida adulta, o que fortalece a hipótese de que a programação dos mecanismos de sinalização de fome e saciedade ocorre no período neonatal, podendo influenciar tanto o apetite quanto o consumo de alimentos na vida adulta (Cripps et al., 2005). Um estudo da OMS reforçou esta ideia ao apontar que o aleitamento pode ter efeitos benéficos de longo prazo, visto que indivíduos amamentados apresentaram na vida adulta: redução de colesterol total e de pressão arterial, diminuição da incidência de diabetes tipo 2, menor prevalência de sobrepeso e obesidade, além de uma melhor performance em testes de inteligência frente a indivíduos que não foram amamentados (Horta et al., 2007).

Entretanto, todos esses benefícios são colocados em risco quando se nota que a prevalência de aleitamento materno exclusivo é de apenas $41 \%$ nas crianças menores de seis meses, como revelado por um levantamento conduzido nas capitais brasileiras e Distrito Federal em 2008. Deve-se ressaltar a variação observada entre as regiões do país: 45,9\% para a região Norte, $45 \%$ no Centro-Oeste, $43,9 \%$ no Sul, $39,4 \%$ no Sudeste e $37 \%$ no Nordeste. O 
tempo de duração do aleitamento materno exclusivo também merece destaque, sendo em média de 54,11 dias, ou seja, 1,8 meses para as capitais brasileiras, muito abaixo do tempo mínimo preconizado para a lactação exclusiva (Brasil, 2009).

Dentre todas as espécies de mamíferos, os filhos / filhotes apresentam alto grau de dependência para com suas mães, tanto para a nutrição propriamente dita, que se traduz na lactação, quanto para suprir as necessidades de interação física. Assim, a interrupção da relação entre mãe e filho / filhote resulta não somente em alterações fisiológicas, mas também em modificações comportamentais (Kikusui e Mori, 2009).

O desmame precoce reflete a curta duração do aleitamento materno exclusivo e a abrupta separação dos filhotes da mãe, além da transferência não gradativa da fonte de nutrientes, com a súbita introdução de ração no lugar do leite materno.

Estudos realizados com roedores desmamados precocemente relatam alterações comportamentais como o aumento persistente da sensação de medo e da sensibilidade a fatores de estresse. Nestes casos, ocorre inclusive uma exacerbação da resposta neuroendócrina, causada possivelmente por uma redução do número de receptores de glicocorticoides da região do hipocampo (Kikusui e Mori, 2009). O desmame precoce também afeta o quanto de cuidado maternal as fêmeas que foram submetidas a esse processo vão dedicar a seus filhotes na vida adulta, visto que elas mesmas tiveram acesso restrito a esse tipo de cuidado (Kikusui e Mori, 2009).

Seguindo-se uma linha temporal no que se refere à alimentação dos ratos, sabe-se que durante o período gestacional a nutrição ocorre por via placentária e, a partir do nascimento, se dá a amamentação. A partir do $14^{\circ}$ dia de vida pós-natal, os ratos abrem os olhos e passam a reconhecer o ambiente e a identificar a ração como um novo alimento. Inicia-se então um período de transição, no qual a dieta torna-se mista, com o consumo de alimento sólido associado ao leite materno. Esta condição permanece até o desmame definitivo que, naturalmente ocorre aos 28 dias de vida, mas para fins experimentais, é induzido no $21^{\circ}$ dia pós-natal (Henning, 1981).

Dessa forma, o período de desmame compreende a substituição gradativa do leite materno pelo alimento sólido e é concomitante a outros processos fisiológicos relacionados à alteração do padrão de dieta. Nessa fase ocorre uma mudança na proporção de macronutrientes ingeridos, com aumento no consumo de carboidratos e decréscimo da quantidade de lípides, o que desencadeia também a alteração do quadro de enzimas digestórias. Paralelamente ao desmame, ocorrem também o desenvolvimento do paladar, a 
maturação morfológica da língua, a abertura das orelhas e a regulação termogênica (Henning, 1981; Koldovský, 1985).

Além de fonte de nutrientes, o leite materno também é composto por diversos peptídeos biologicamente ativos, como hormônios e fatores de crescimento, capazes de estimular o crescimento do trato gastrintestinal e sua maturação funcional (Donovan e Odle, 1994; Koldovský, 1989; Koldovský et al., 1995; Xu, 1996), já que o animal neonato necessita de um período até que seja capaz de sintetizar seus próprios hormônios e fatores de crescimento em concentrações adequadas para exercerem suas funções (Gama e Alvares, 1996; Penttila et al., 1998; Smith e Ojeda, 1984).

Dada a importância das fases de lactação e desmame, visto que a ingestão do leite materno não só nutre os filhotes, mas seus peptídeos biologicamente ativos têm funções fundamentais ao desenvolvimento adequado dos mesmos, perturbações do padrão alimentar durante esse período podem interferir no desenvolvimento dos animais (Koldovský, 1985).

Lima et al. (2011) utilizaram um modelo de desmame precoce aos 17 dias sem separação materna, mas com impedimento de acesso à amamentação por bloqueio mecânico, e mostraram os seguintes efeitos na vida adulta: aumento de peso corporal e adiposidade visceral, hipertrigliceridemia, hiperglicemia com sinais de resistência insulínica e hiperleptinemia associada à resistência hipotalâmica a esse hormônio, caracterizando um quadro de desenvolvimento de síndrome metabólica.

Sabe-se que modificações da condição alimentar alteram o processo proliferativo da mucosa gástrica, de forma que em animais lactentes ocorre um estímulo durante o jejum (Alvares, 1992; Alvares e Gama, 1993). Em animais jovens, aos 30 dias, há inibição da proliferação nesta situação, enquanto animais de 22 dias não são responsivos à privação alimentar. Pode-se então inferir que há uma relação entre a fase de desenvolvimento do animal e o tipo de resposta proliferativa que a condição alimentar provoca (Alvares e Gama, 1993).

A drástica mudança representada pelo desmame precoce estressa os filhotes (Figueiredo, 2010; Lin et al., 1998), aumenta em cinco vezes a incidência de erosões gástricas (Ackerman et al., 1978) e a predisposição à ocorrência de lesões ulcerativas mais profundas (Glavin e Pare, 1985). Alterações nas funções digestivas e proliferativas também decorrem do desmame precoce, como mostrado por Gama e Alvares (2000), que verificaram que há inibição da proliferação celular no estômago quando filhotes submetidos a esse padrão são mantidos em jejum, sugerindo que esta mudança da dieta leva ao surgimento de uma resposta típica de outra fase da vida do animal. 
Lin et al. (2001) demonstraram que o desmame precoce também eleva a atividade da enzima ornitina descarboxilase (ODC), além de induzir a atividade do pepsinogênio, indicando a aceleração do desenvolvimento funcional gástrico. Outros estudos revelaram que a antecipação da substituição do leite pelo alimento sólido promove a diferenciação de células mucosas do colo, consideradas marcadoras da maturação do estômago, assim como causa um aumento dos níveis do fator de crescimento transformante $\alpha$ (TGF $\alpha$ ) e do receptor do fator de crescimento epidermal (EGFR) no epitélio gástrico (Osaki et al., 2010).

Além do TGF $\alpha$, o fator de crescimento transformante $\beta$ (TGF $\beta$ ) também é susceptível às alterações impostas pela dieta do animal e por sua condição alimentar. Alvares et al. (2007) mostraram que animais lactentes sob efeito de jejum apresentam redução dos níveis da isoforma TGFß3, fato confirmado por Ogias et al. (2010), que também relataram diminuição nos níveis do receptor-I (TRRI) de TGFß na mesma condição. Entretanto, durante o desmame precoce, a privação alimentar aumenta os níveis de TGF $\beta 3$ e T $\beta R I$ na mucosa gástrica (Ogias et al., 2010).

Assim, os efeitos já conhecidos do desmame precoce permitem inferir que o leite materno age como um fator modulador da proliferação celular na mucosa gástrica, bem como de seu desenvolvimento funcional (Gama e Alvares, 2000; Lin et al., 2001; Ogias et al., 2010; Osaki et al., 2010, 2011), atuando em conjunto com peptídeos biologicamente ativos nele contido (De Andrade Sá et al., 2008; Gama e Alvares, 1996).

\subsection{Estômago}

O estômago caracteriza-se como uma dilatação do tubo digestório, situada entre o esôfago e o intestino delgado e é responsável pela execução de inúmeras funções, dentre atividades exócrinas, endócrinas e motilidade. Nos ratos esse órgão se estrutura em três regiões histologicamente distintas: córnea, corpo e antro (Johnson, 1985; Lee et al., 1982).

A região córnea, contígua ao esôfago, apresenta epitélio estratificado queratinizado. Já as regiões do corpo e do antro gástrico caracterizam-se por epitélio simples secretor, com a presença de glândulas tubulares que se abrem em fossetas para a luz gástrica (Lee et al., 1982). As glândulas do corpo, localizado na porção mediana do estômago, são longas e podem ser subdivididas em três segmentos distintos no rato adulto: istmo, colo e base (Helander, 1981).

As glândulas gástricas são revestidas por diferentes tipos de células epiteliais que se originam a partir de células-tronco localizadas na região do istmo. Cada linhagem gerada tem 
características migratórias, secretórias e tempo de turnover próprios (Brittan e Wright, 2004; Karam, 1998; Karam e Leblond, 1993a). Assim, as células precursoras das linhagens celulares gástricas maduras são: célula pré-mucosa superficial, célula pré-parietal, célula pré-mucosa do colo e célula pré-enteroendócrina (Karam, 1993; Karam e Leblond, 1993b, c, d).

A célula pré-mucosa superficial migra do istmo em sentido ascendente para a região da fosseta e se diferencia em célula mucosa superficial, que reveste a superfície luminal do estômago e as fossetas gástricas. Essa linhagem é responsável pela secreção de muco e seu período de turnover é de 3 dias (Karam e Leblond, 1993b). Já a célula pré-parietal completa seu processo de diferenciação em célula parietal na região do istmo e então migra em sentido bidirecional, embora seja predominantemente identificada nas regiões de istmo e colo, secretando íons que formarão o ácido clorídrico na luz do estômago. O tempo estimado para seu turnover é de 54 dias (Ekelund et al., 1985; Helander, 1981; Karam, 1993, 1998).

A célula pré-mucosa do colo migra do istmo em sentido descendente para a região do colo, na qual se diferencia em célula mucosa do colo, também secretora de muco. De acordo com os estudos de Karam e Leblond (1993c), este tipo celular permanece como "mucosa do colo" por um período aproximado de 7 a 14 dias, após o qual continua migrando em direção à base glandular, onde se diferencia novamente em célula zimogênica, passando por um estágio intermediário de célula pré-zimogênica. Keeley e Samuelson (2010) detectaram a coexpressão de marcadores específicos para células mucosa do colo e zimogênica em um mesmo tipo celular na mucosa de animais recém-nascidos. Estes marcadores só foram encontrados individualmente uma semana após o nascimento, sugerindo que a transição entre célula mucosa do colo e célula zimogênica passa por um estágio em que apresenta características de ambos os tipos celulares.

As células zimogênicas encontram-se na porção basal da glândula gástrica e são responsáveis pela hidrólise proteica ocorrida no estômago, já que secretam o pepsinogênio, que é convertido à pepsina em contato com o meio ácido gerado pela atividade das células parietais. Essa linhagem tem um período de turnover de 194 dias, o mais longo dentre as células epiteliais gástricas (Ekelund et al., 1985; Helander, 1981; Johnson, 1985; Karam e Leblond, 1993c).

A célula pré-enteroendócrina acompanha o mesmo perfil descrito para a célula parietal, ou seja, se diferencia em célula enteroendócrina na região do istmo glandular e migra bidirecionalmente, embora seja encontrada em maior quantidade na porção basal da glândula gástrica (Helander, 1981; Karam, 1998, 1999; Karam e Leblond, 1993d;). As células enteroendócrinas representam linhagens distintas que são responsáveis pela síntese de 
diversos hormônios, entre os quais: histamina, secretada pelas células ECL (enterochromaffin-like), gastrina pelas células $\mathrm{G}$ presentes na região do antro gástrico, somatostatina pelas células D (Helander, 1981) e ghrelina pelas células "X/A-like" (Date et al., 2000a; Kojima et al., 1999). O turnover para as células enteroendócrinas é estimado em torno de 60 dias na região do corpo gástrico (Karam e Leblond, 1993d).

O antro, localizado na porção distal do estômago, apresenta glândulas curtas e enoveladas, compostas predominantemente por células mucosas e enteroendócrinas. As células parietais e zimogênicas são escassas ou mesmo ausentes nessa região do estômago, o que torna a porção do corpo gástrico a maior responsável pela secreção de ácido clorídrico e pepsinogênio (Helander, 1981).

A morfogênese das glândulas gástricas ocorre tardiamente nos fetos de rato e acarreta modificações morfológicas e fisiológicas importantes (Alvares, 1994). Durante esse processo diversos fatores interagem e favorecem a maturação do epitélio do estômago, influenciando a proliferação, a migração, a diferenciação e a morte celular. Dentre eles estão o programa genético, hormônios, fatores de crescimento, a microbiota, a dieta e o estado nutricional tanto do animal, quanto da própria mãe durante as fases de gestação e lactação (De Andrade Sá et al., 2008; Lee e Lebenthal, 1983; Nanthakumar et al., 2005; Young et al., 1987).

Embora a diferenciação entre as linhagens celulares da mucosa do estômago se inicie entre o meio e o final da gestação nos ratos, as glândulas gástricas se encontram completamente funcionais somente em torno da terceira semana de vida pós-natal, período que coincide com o desmame nesses animais (Keeley e Samuelson, 2010).

\subsection{Ghrelina}

A ghrelina é um hormônio peptídico de 28 aminoácidos sintetizado principalmente no estômago (Kojima et al., 1999). A origem de seu nome deriva do termo proveniente do prefixo ghre, que significa "crescimento" nas linguagens "Proto-Indo-Europeias", em referência ao estímulo à liberação de hormônio de crescimento $(\mathrm{GH})$ que acarreta (Kojima e Kangawa, 2005). É sintetizada principalmente no estômago, embora outros órgãos também contribuam para sua síntese, mesmo em menores quantidades: intestino delgado, cólon, hipotálamo, hipocampo, hipófise, pâncreas, rins, entre outros, tanto em humanos, quanto em ratos (Date et al., 2000a, 2002; Hosoda et al., 2000a; Sato et al., 2005, 2012; Ueberberg et al., 2009). 
A célula enteroendócrina "X/A-like" é a responsável pela síntese de ghrelina no estômago do rato e representa aproximadamente $20 \%$ da população de células enteroendócrinas da glândula gástrica da região do corpo do estômago de um rato adulto. Este tipo celular está distribuído principalmente entre o colo e a base da glândula e caracteriza-se por ser uma célula do tipo fechado em sua maioria, ou seja, sem comunicação direta com o lúmen gástrico, porém intimamente associada à rede de capilares da lâmina própria. Células que sintetizam ghrelina e mantêm contato direto com o lúmen, as do tipo aberto, são encontradas em número muito baixo no estômago, mas representam mais de $60 \%$ nas regiões do trato gastrointestinal do íleo, ceco e cólon (Date et al., 2000a; Sakata et al., 2002).

A ghrelina se origina de um peptídeo de 117 aminoácidos, a pré-pró-ghrelina, e exibe uma particularidade em seu terceiro aminoácido, uma serina, que é a presença de um grupo acil modificando sua estrutura. Essa acilação é considerada uma característica ímpar da ghrelina e é fundamental para o reconhecimento do hormônio pelo receptor secretagogo de hormônio de crescimento, GHS-R (growth hormone secretagogue receptor) e, consequentemente, para que possa exercer suas funções (Kojima et al., 1999). Como mostrado na Figura 1, a ghrelina é bem conservada entre humanos e ratos, com alteração de apenas 2 aminoácidos entre as formas de cada uma das espécies, o que sugere um papel fisiológico importante (Kojima et al., 1999; Wren et al., 2000).

Figura 1 - Sequência de aminoácidos que compõem a ghrelina em humanos e ratos.

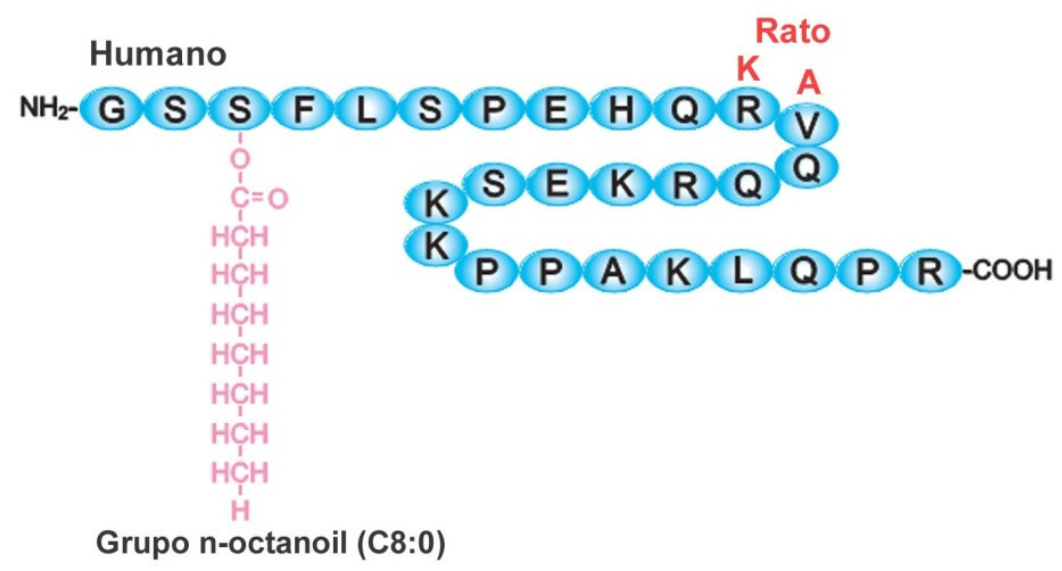

FONTE: Adaptado de Kojima e Kangawa (2005).

Hosoda et al. (2000b) identificaram no estômago de ratos uma segunda molécula de ghrelina gerada por splicing alternativo, que tem 27 aminoácidos e só difere da original pela ausência da glutamina que ocupa a posição 14 na sequência formadora do peptídeo. Portanto, 
a "des-Gln14-ghrelina" também apresenta acilação e é idêntica à ghrelina em termos funcionais, mas é encontrada em proporção muito menor quando comparada à forma de 28 aminoácidos (Kojima e Kangawa, 2005). Além da “des-Gln14-ghrelina”, a forma não acilada da ghrelina ("des-acil-ghrelina”), também foi identificada no estômago e no plasma sanguíneo, sendo que a "des-acil-ghrelina" é a forma predominante em ambos, correspondendo à proporção de 2:1 no estômago. Entretanto, a "des-acil-ghrelina" não é funcional no que diz respeito às atividades endócrinas próprias da ghrelina, mas há investigações no sentido de esclarecer se há um receptor específico para essa forma, e se ela exerceria funções distintas daquelas da ghrelina acilada (Hosoda et al., 2000a; Kojima e Kangawa, 2005).

A enzima responsável pela adição de uma cadeia de ácido-graxo à ghrelina pertence à família das MBOATs (membrane bound O-acyltransferase), e é denominada GOAT (ghrelin O-acyltransferase). Apresenta-se bem conservada nos vertebrados, com aproximadamente 90\% de homologia na sequência de aminoácidos entre humanos, ratos e camundongos. Sua especificidade é tal, que a forma acilada da ghrelina não é encontrada no plasma sanguíneo de camundongos knock-out para a GOAT (Gutierrez et al., 2008; Yang et al., 2008).

A acilação ocorre exclusivamente na serina que ocupa a terceira posição na cadeia de aminoácidos da ghrelina (serina-3) e a GOAT apresenta seletividade entre os tipos de ácidos graxos que serão utilizados na acilação, sendo que os ácidos octanoico e decanoico são as duas formas mais utilizadas, havendo ainda preferência para o primeiro, embora outros tipos de ácidos graxos também possam ser utilizados (Gutierrez et al., 2008; Kojima et al., 1999; Yang et al., 2008). Gutierrez et al. (2008) sugeriram a possibilidade de haver algum tipo específico de metabolismo de ácidos graxos nas células "X/A-like" que priorize a disponibilização dos ácidos octanoico e decanoico para a GOAT catalisar a acilação da ghrelina. Acredita-se que essa modificação pós-traducional seja essencial para permitir que a ghrelina passe pela barreira hemato-encefálica, conferindo o acesso a regiões específicas do cérebro nas quais o receptor GHS-R está presente (Banks et al., 2002).

Sabe-se que os ácidos graxos e triglicérides (ambos de cadeia média) ingeridos com a dieta interferem no tipo de ácido graxo que será utilizado para a acilação da ghrelina, ou seja, o número de carbonos dos ácidos graxos ligados à ghrelina recém acilada corresponde àquele ingerido com a dieta (Nishi et al., 2005a; Sato et al., 2012). Portanto, deve-se ressaltar que a síntese de ghrelina e sua secreção na forma acilada constituem dois processos diferentes, visto que o sistema "GOAT-ghrelina" é dependente de determinados tipos de ácidos graxos, os quais não interferem com o controle da síntese de ghrelina em si (Romero et al., 2010). 
Em concordância com os estudos de Kojima et al. (1999) que indicaram que a síntese de ghrelina ocorre principalmente no estômago, este também é o órgão que mais expressa GOAT (Gutierrez et al., 2008; Yang et al., 2008). Além disso, outros trabalhos demonstraram alto grau de colocalização (em torno de 95\%) de ghrelina e GOAT em células "X/A-like" na mucosa gástrica de camundongos (Sakata et al., 2009; Stengel et al., 2010). Já para os ratos, o grau de colocalização é menor, em torno de $56 \%$, enquanto os outros $44 \%$ de células que expressam GOAT foram identificadas como células enteroendócrinas ECL. Assim, a ghrelina parece ser acilada não somente pelas células "X/A-like" nos ratos, mas também pelas células ECL gástricas que expressam GOAT (Stengel et al., 2010).

Da síntese do pré-pró-peptídeo à ghrelina acilada, acredita-se que ocorram as seguintes etapas: a pré-pró-ghrelina sofre a clivagem do peptídeo sinal, que resulta em uma sequência de 94 aminoácidos denominada pró-ghrelina. Em seguida ocorre a modificação póstraducional mediada pela ação da enzima GOAT. Posteriormente, a pró-hormônio convertase 1/3 (PC 1/3) atua sobre a pró-ghrelina acilada, gerando 2 subprodutos: a ghrelina acilada, correspondente ao fragmento N-terminal do precursor, e a obestatina, correspondente ao fragmento C-terminal do precursor (Gutierrez et al., 2008; Romero et al., 2010; Yang et al., 2008; Zhu et al., 2006). A Figura 2 esquematiza esse processo.

A obestatina é um peptídeo de 23 aminoácidos ao qual foram atribuídas funções contrárias as da ghrelina. Dessa forma, a obestatina seria responsável por inibir a ingestão de alimentos, suprimir o esvaziamento gástrico e a motilidade intestinal e estaria associada à redução de massa corpórea. Entretanto, essas atribuições não foram confirmadas por estudos subsequentes, o que acarretou no questionamento do real papel da obestatina que, até o momento, ainda não foi completamente elucidado (Sato et al., 2012; Zhang et al., 2005).

A ghrelina apresenta diversas funções fisiológicas, dentre elas estão o estímulo da liberação de GH (Date et al., 2000b; Kojima et al., 1999), da secreção de ácido gástrico (Date et al., 2001; Masuda et al., 2000) e da motilidade do estômago (Masuda et al., 2000); o estímulo à formação óssea, com aumento de proliferação e diferenciação de osteoblastos (Fukushima et al., 2005); o aumento do apetite, da ingestão alimentar (Nakazato et al., 2001; Shintani et al., 2001; Tschöp et al., 2000) e o favorecimento do ganho de peso em ratos, caracterizando-a como um hormônio orexigênico (Cummings et al., 2001; Nakazato et al., 2001; Tschöp et al., 2000), diretamente relacionado ao comportamento alimentar e à homeostase energética (Nakazato et al., 2001; Tschöp et al., 2000; Wren et al., 2000). 
Figura 2 - Modificação pós-traducional da pró-ghrelina.

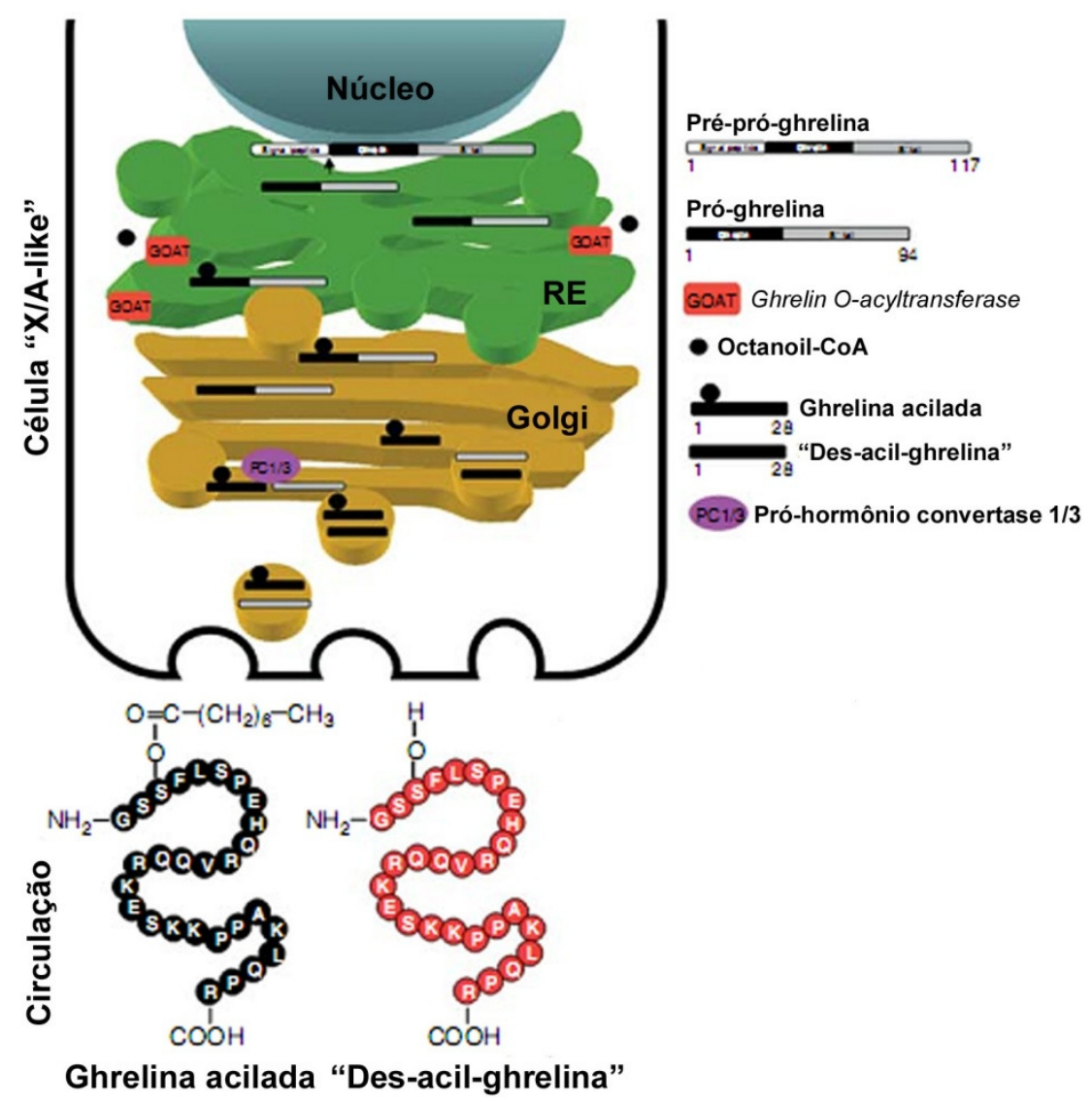

FONTE: Adaptado de Romero et al. (2010).

Alguns estudos vêm relacionando a ghrelina com a proliferação celular maligna, característica do câncer, possivelmente através de um mecanismo autócrino / parácrino, ainda não completamente descrito (De Vriese e Delporte, 2007; Jeffery et al., 2003; Nikolopoulos et al., 2010; Waseem et al., 2008). Sabe-se também que a ghrelina inibe o processo apoptótico em algumas linhagens celulares, como cardiomiócitos (Baldanzi et al., 2002), células intestinais (Park et al., 2008) e células neuronais em processo de isquemia (Chung et al., 2007).

Sánchez et al. (2004), em seu estudo sobre o ritmo dos hormônios ghrelina e leptina, concluíram que ambos estão nitidamente relacionados à ingestão alimentar. Ratos com 3 meses de idade submetidos a um ciclo de 12/12 horas de claro/escuro, apresentaram altos níveis gástricos de ghrelina na fase de claro, coincidente com seu período de jejum, visto que a alimentação dos roedores concentra-se no período noturno (77\%). Esses níveis permaneceram altos até o início da fase de escuro, quando houve uma queda abrupta, no momento da alimentação. Dessa forma, os autores demonstraram uma correlação inversa 
entre os níveis de ghrelina e a ingestão de alimento, que também é válida em relação ao conteúdo gástrico e aos níveis plasmáticos de leptina.

Assim como o desmame precoce, o desmame tardio também representa uma perturbação do padrão alimentar, pois retarda a introdução de alimento sólido à dieta, já que se baseia no prolongamento do período de lactação exclusiva. Fåk et al. (2007) demonstraram que o desmame tardio reduziu as concentrações de ghrelina no estômago e no plasma sanguíneo e sugeriram que o desmame pode ser um fator importante na regulação da expressão gástrica desse peptídeo.

\subsection{Receptor GHS-R}

Até recentemente o GHS-R, receptor secretagogo de hormônio de crescimento, era utilizado como alvo de ligantes sintéticos que estimulam a liberação do GH, os secretagogos de GH (GHS). Diferentemente do estímulo gerado pela associação do hormônio liberador do hormônio de crescimento (GHRH) ao seu receptor GHRH-R, que utiliza como segundo mensageiro o monofosfato cíclico de adenosina (AMPc) intracelular para sinalizar o aumento da liberação de $\mathrm{GH}$, os ligantes sintéticos agem por meio do GHS-R e aumentam a concentração intracelular de cálcio via inositol 1, 4, 5-trifosfato $\left(\mathrm{IP}_{3}\right)$, que causa a subsequente elevação do GH. Ambos, GHS e GHRH, agem de maneira independente e sinérgica no estímulo à liberação do GH (Akman et al., 1993; Blake e Smith, 1991; Cheng et al., 1989, 1991).

Howard et al. (1996) revelaram que o GHS-R é um receptor acoplado à proteína G (GPCR) e sugeriram que os ligantes sintéticos GHS mimetizam a ação de uma molécula endógena ainda não identificada. Então, Kojima et al. (1999) realizaram um experimento de farmacologia reversa na tentativa de encontrar este ligante do GHS-R, até então considerado um receptor órfão. Assim, uma linhagem celular expressando GHS-R de rato foi exposta a extratos de cérebro, pulmão, coração, rim, estômago e intestino, e por monitoramento das concentrações intracelulares de cálcio, foi detectada maior atividade em resposta ao extrato de estômago, órgão do qual a ghrelina pode ser purificada e identificada. A Figura 3 mostra a regulação da liberação do GH hipofisário pelos dois receptores: GHRH-R e GHS-R.

Como um típico receptor do tipo GPCR, o GHS-R exibe sete domínios transmembrana e apresenta-se sob duas formas, denominadas $1 \mathrm{a}$ e $1 \mathrm{~b}$, sendo a segunda gerada por splicing alternativo. O gene do GHS-R é formado por 2 éxons e 1 íntron, sendo que o primeiro éxon codifica os domínios transmembrana de 1 a 5, enquanto o segundo codifica os domínios 6 e 7. 
Assim, o GHS-R1a deriva de ambos os éxons, resulta em um GPCR clássico com 7 domínios transmembrana, e responde pelas atividades da ghrelina. Já o GHS-R1b deriva do primeiro éxon apenas, resultando em um receptor truncado, com 5 domínios transmembrana somente e funcionalmente inativo (Howard et al., 1996; Kojima e Kangawa, 2005; McKee et al., 1997).

Figura 3 - Liberação de GH pela hipófise por meio dos receptores GHRH-R e GHS-R.

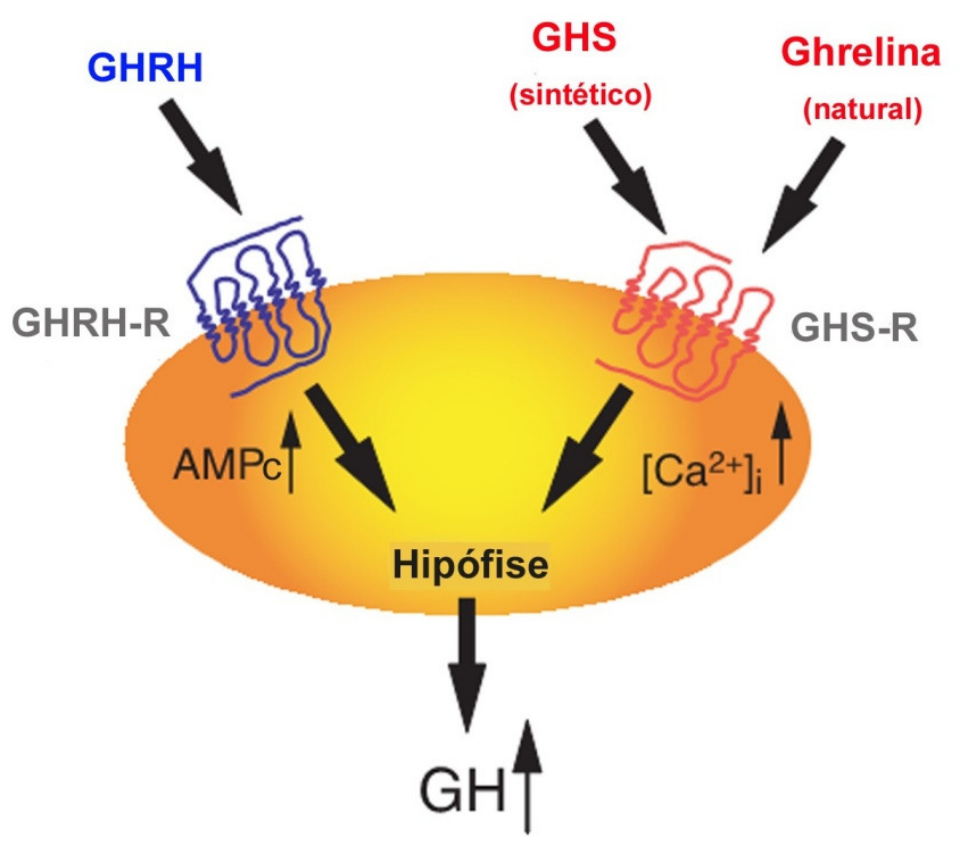

FONTE: Adaptado de Kojima e Kangawa (2005).

O GHS-R1a está distribuído em duas áreas no cérebro: hipófise e hipotálamo (Howard et al., 1996). Sua expressão na hipófise é consistente com o aumento da liberação de GH provocado pela ghrelina, enquanto sua expressão no hipotálamo, principalmente na região do núcleo arqueado, é crucial para as atividades orexigênicas da ghrelina (Camiña, 2006; Tannenbaum et al., 1998). Além dessas áreas, o GHS-R1a também é encontrado em diversos tecidos, como: estômago, intestino, pâncreas, baço, tireoide, coração, pulmão, glândula adrenal, testículo e ovário (Dass et al., 2003; Gnanapavan et al., 2002; Kojima e Kangawa, 2005; Shuto et al., 2001; Ueberberg et al., 2009). Esta vasta distribuição periférica do GHSR1a sugere que a ghrelina possa ter outras funções que não somente o estímulo à liberação de GH e a participação no controle da homeostase energética (Camiña, 2006; Gnanapavan et al., 2002).

A forma truncada do receptor, GHS-R1b, também é amplamente distribuída em diferentes tecidos, muitas vezes até em níveis maiores que o GHS-R1a (Gnanapavan et al., 
2002). Entretanto, até o presente momento, o significado funcional da presença desta isoforma é desconhecido, mas não se descarta a possibilidade de haver um ligante endógeno ainda não identificado para o GHS-R1b (Camiña, 2006; Gnanapavan et al., 2002).

Como mencionado anteriormente, há estudos mostrando que tanto a ghrelina quanto o receptor GHS-R estão presentes em diferentes tipos de tumor e sugerem que a ghrelina atua possivelmente através de mecanismos autócrinos / parácrinos na proliferação maligna e carcinogênese (De Vriese e Delporte, 2007; Jeffery et al., 2003; Nikolopoulos et al., 2010; Waseem et al., 2008).

Waseem et al., (2008) demonstraram que a expressão de ghrelina e de GHS-R1b está aumentada no câncer colorretal e seu aumento é gradativo, de acordo com o estágio de malignidade do tumor. Ao contrário, a expressão de GHS-R1a diminui drasticamente. Esse achado sugere que a ghrelina possivelmente age no controle proliferativo maligno e pode favorecer o comportamento invasivo do tumor através do GHS-R1b ou ainda através de outro receptor ainda não identificado. Deve-se ressaltar que, embora os níveis teciduais de ghrelina sejam altos, os níveis plasmáticos medidos em jejum não podem ser correlacionados com o estágio de progressão de tumor, mas sim com a condição metabólica do indivíduo. Isto reforça a ideia de que a ação da ghrelina e seus receptores em tumores está associada a um mecanismo autócrino / parácrino, e não à regulação endócrina pela qual este hormônio exerce suas atividades clássicas (Waseem et al., 2008).

\section{5 [D-Lys-3]-GHRP-6}

Os secretagogos de GH, conhecidos como GHS, são componentes sintéticos peptídicos ou não peptídicos capazes de estimular a liberação de GH de maneira dosedependente. São considerados compostos importantes na prática clínica, visto que alguns GHS podem ser indicados como agentes terapêuticos nos casos de deficiência idiopática de GH em crianças e adultos, como estimuladores de processos anabólicos em idosos e ainda podem ser utilizados como coadjuvantes no tratamento de processos catabólicos debilitantes, como a osteoporose e a AIDS (Inui, 2001).

Um dos GHS mais conhecidos, o hexapeptídeo GHRP-6 foi sintetizado em 1984 e mostrou atividade específica e dose-dependente no estímulo à liberação de GH in vitro e in vivo, já que outros hormônios hipofisários, como o estimulante da tireoide (TSH), o luteinizante (LH), o folículo-estimulante (FSH) e a prolactina (PRL), não responderam ao uso deste sintético. Além disso, a administração crônica do GHRP-6 em ratas promoveu aumento 
significativo de massa corpórea (Bowers et al., 1984; Momany et al., 1984), o que foi confirmado e ampliado pelo estudo de Lall et al. (2001) que revelaram que o GHRP-6 promove aumento da adiposidade, do consumo de alimento e dos níveis séricos de leptina em camundongos, sugerindo uma atividade orexigênica.

Cheng et al. (1989) revelaram que [D-Lys-3]-GHRP-6, um análogo do GHRP-6 obtido através da substituição da alanina pela lisina na posição 3 da sequência de aminoácidos, inibe o estímulo que o GHRP-6 provoca na liberação de GH de maneira dose-dependente e por meio do mesmo receptor por ele utilizado, atualmente identificado como GHS-R.

No experimento que resultou na identificação da ghrelina realizado por Kojima et al. (1999), o peptídeo [D-Lys-3]-GHRP-6 foi utilizado como antagonista do GHS-R e ficou demonstrado que o aumento da concentração de cálcio intracelular promovido pela ligação da ghrelina ao receptor foi inibido em sua presença. Entretanto, uma dose maior de ghrelina foi capaz de reestabelecer os níveis de cálcio intracelular observados na ausência do antagonista, sugerindo assim que [D-Lys-3]-GHRP-6 atua como um antagonista competitivo.

No estudo de Asakawa et al. (2003) o uso de [D-Lys-3]-GHRP-6 diminuiu significativamente a ingestão de alimento de maneira dose-dependente tanto em camundongos alimentados com uma dieta padrão (12\% de gordura), quanto em camundongos alimentados com uma dieta rica em gorduras (45\% de gordura). Camundongos obesos (ob/ob) também apresentaram queda no consumo alimentar, além de redução no ganho de peso após um tratamento com o peptídeo em questão a cada 12 h por 6 dias consecutivos. Outros estudos reforçam esta ingestão alimentar reduzida associada ao uso de [D-Lys-3]-GHRP-6, como os trabalhos de Beck et al. (2004) e Xin et al. (2006). O comprometimento das taxas de esvaziamento gástrico também é relatado com o uso desta molécula (Asakawa et al., 2003; Kitazawa et al., 2005).

Desde a associação de [D-Lys-3]-GHRP-6 com a ghrelina no sentido de contrapor as suas atividades, atuando de forma anorexigênica, esta molécula foi adotada e é utilizada como antagonista do receptor GHS-R, apesar da escassez de informações farmacológicas relativas a este peptídeo na literatura. 


\section{JUSTIFICATIVA}

Sabe-se da importância da amamentação no crescimento e desenvolvimento saudáveis do organismo (Horta et al., 2007; WHO, 2001), de seu aspecto comportamental e afetivo (Kikusui e Mori, 2009), assim como de seus efeitos protetores que se refletem inclusive na vida adulta (Harder et al., 2005; Horta et al., 2007; Lima et al., 2011). Dentro deste contexto estão o leite materno e seus peptídeos biologicamente ativos que influenciam o crescimento, o desenvolvimento e a maturação funcional da mucosa gástrica (Donovan e Odle, 1994; Koldovský, 1989; Koldovský et al., 1995; Xu, 1996), e o desmame precoce, que altera a proliferação celular gástrica e acelera o processo de maturação do estômago (Gama e Alvares, 2000; Lin et al., 2001; Osaki et al., 2010, 2011).

Tendo em vista que a ghrelina é um hormônio diretamente relacionado com o apetite, ingestão alimentar e regulação da homeostase energética (Nakazato et al., 2001; Tschöp et al., 2000; Wren et al., 2000), e que os mecanismos de sinalização de fome e saciedade sofrem influências dos acontecimentos relativos ao período neonatal, podendo acarretar uma programação metabólica alterada (Cripps et al., 2005; Horta et al., 2007), a hipótese do nosso estudo é a de que o desmame precoce induz alterações na síntese de ghrelina e de seu receptor, e que este hormônio pode estar envolvido na regulação da proliferação celular do epitélio gástrico, que acaba por refletir no crescimento e maturação do estômago. 


\section{OBJETIVOS}

O objetivo deste estudo foi investigar se o desmame precoce promove alterações na expressão e distribuição de ghrelina e de seu receptor na mucosa gástrica de ratos em desenvolvimento e verificar a relação deste hormônio com a proliferação celular do tecido epitelial no estômago.

Dessa forma, nossos objetivos específicos foram:

a) caracterizar a distribuição de ghrelina e do receptor GHS-R na mucosa gástrica de ratos durante a terceira semana de vida pós-natal e avaliar o efeito do desmame precoce sobre estas moléculas;

b) bloquear a ação da ghrelina durante o desmame precoce, através do uso de um inibidor específico de sua atividade, para observar o efeito sobre a proliferação da mucosa gástrica e verificar se este hormônio contribui para o controle do crescimento do estômago. 


\section{MATERIAL E MÉTODOS}

\subsection{Animais e desmame precoce}

Foram utilizados ratos albinos, Rattus norvegicus, linhagem Wistar. Os animais foram mantidos no Biotério do Departamento de Biologia Celular e do Desenvolvimento do Instituto de Ciências Biomédicas da Universidade de São Paulo (ICB - USP). Permaneceram sob condições normais, em um ciclo de 12/12 horas de claro/escuro, com exaustão e temperatura $\left(21{ }^{\circ} \mathrm{C}\right.$ a $\left.24{ }^{\circ} \mathrm{C}\right)$ controladas. $\mathrm{O}$ protocolo referente às condições de alojamento e experimentação foi aprovado pela Comissão de Ética em Uso de Animais (CEUA 86/2008, 80/2011).

As fêmeas foram acasaladas e alojadas em gaiolas individuais sob as condições já descritas, com acesso ad libitum à ração e água. O dia do nascimento das ninhadas foi designado como dia zero e, no $2^{\circ}$ dia de vida pós-natal, as ninhadas foram remanejadas para que tivessem 8 ou 9 filhotes por fêmea, os quais foram amamentados até o $14^{\circ}$ dia. Animais de ambos os sexos foram utilizados no estudo.

Aos 15 dias de vida, às 10 horas, os filhotes foram divididos em 2 grupos de tratamento: controle AS e desmame precoce (DP). Os animais do grupo C permaneceram com suas mães, sendo amamentados normalmente, até o momento da eutanásia. Já os animais do grupo DP foram separados de suas mães e alojados em gaiolas menores, nas quais a dieta era uma pasta de ração (Nuvilab CR-1, Nuvital Nutrientes SA, Colombo, PR, Brasil), além dos pellets, ambos disponíveis durante todo o tempo (Gama e Alvares, 2000). Duas vezes ao dia, os filhotes do grupo DP receberam a pasta de ração e água individualmente, através de pipeta descartável, assim como foram massageados na região abdominal para facilitar a eliminação de urina e fezes. Esse tratamento ocorreu até o $18^{\circ}$ dia de vida pós-natal. A massa corpórea dos filhotes foi monitorada durante todo o processo.

\subsection{Tratamento com [D-Lys-3]-GHRP-6}

Com o objetivo de avaliar o papel da ghrelina no processo de proliferação celular na mucosa gástrica na condição de desmame precoce, foi realizado um tratamento com [D-Lys3]-GHRP-6, um análogo do secretagogo sintético do hormônio de crescimento GHRP-6, que se liga ao receptor de ghrelina, GHS-R, promovendo efeitos anorexígenos, antagonizando a ação da ghrelina (Asakawa et al., 2003; Kojima et al., 1999). 
O dia para o tratamento com a referida droga foi estipulado com base em resultados sobre a distribuição gástrica de ghrelina na condição de desmame precoce, experimento que foi realizado previamente ao uso de [D-Lys-3]-GHRP-6, visto que era necessário conhecer a ocorrência e a variação da ghrelina para a definição dos parâmetros de tratamento.

Assim, os animais foram mantidos como descrito na seção 4.1, desmamados precocemente no $15^{\circ}$ dia de vida pós-natal e subdivididos em dois grupos: desmame precoce (DP), que representa o grupo controle nesse experimento, e desmame precoce tratado com antagonista [D-Lys-3]-GHRP-6 (Phoenix Pharmaceuticals, Inc., Burlingame, CA, EUA) (DPA). No $17^{\circ}$ dia os animais DPA receberam a droga via injeção i.p. em dois horários, $10 \mathrm{~h}$ e 17 h (Figura 4). Os animais do grupo DP receberam o veículo utilizado para diluição da droga, solução salina a $0,9 \%$, nos mesmos horários e volumes que os animais DPA.

Foram realizados dois experimentos com a referida droga, aqui designados por DPA [5] e DPA - [10], com alterações na diluição e na dose administradas, como descrito na Tabela 1.

Tabela 1 - Caracterização dos experimentos com [D-Lys-3]-GHRP-6

\begin{tabular}{ccc}
\hline Características & DPA $-[\mathbf{5}]$ & DPA - [10] \\
\hline Tratamento & 1 dose às $10 \mathrm{~h}$ e 1 dose $17 \mathrm{~h}$ & 1 dose às $10 \mathrm{~h}$ e 1 dose $17 \mathrm{~h}$ \\
Dose & $5 \mu \mathrm{g} / \mathrm{g}$ de massa corpórea & $10 \mu \mathrm{g} / \mathrm{g}$ de massa corpórea \\
Diluição & $0,5 \mathrm{mg} / \mathrm{mL}$ & $1 \mathrm{mg} / \mathrm{mL}$ \\
Veículo & Salina $0,9 \%$ autoclavada & Salina $0,9 \%$ autoclavada \\
\hline
\end{tabular}

FONTE: Bittar-Rodrigues (2012).

A droga foi administrada após a oferta de alimento aos filhotes com o intuito de evitar possíveis reduções na ingestão alimentar do grupo DPA, visto que o antagonista [D-Lys-3]GHRP-6 tem efeitos notadamente anorexígenos (Asakawa et al., 2003; Beck et al., 2004; Xin et al., 2006).

Para avaliar a proliferação celular, no $18^{\circ}$ dia, os filhotes receberam uma dose i.p. de Bromodeoxiuridina (5-bromo-2-deoxiuridina - BrdU - $100 \mathrm{mg} / \mathrm{kg}$ de massa corpórea Sigma-Aldrich, Saint Louis, MO, EUA) 1 hora antes da eutanásia, para marcação das células em fase de síntese de DNA. 


\subsection{Coleta de amostras}

A eutanásia dos animais e a coleta dos estômagos para a realização de análise morfológica, ensaios de imuno-histoquímica para ghrelina, RT-PCR (Reverse transcription polymerase chain reaction - Reação em cadeia da polimerase com transcriptase reversa) para GHS-R e Western blot para ghrelina e GHS-R ocorreram nas idades de 15, 16, 17 e 18 dias de vida pós-natal para os grupos $\mathrm{C}$ e DP.

Já para a análise de proliferação celular, através da imuno-histoquímica para BrdU, foram utilizadas amostras de filhotes de 18 dias de vida pós-natal desmamados precocemente, grupos DP e DPA (Figura 4), como mencionado anteriormente.

Cada grupo de estudo, C, DP e DPA, foi composto por, no mínimo, 3 animais para cada idade.

A coleta dos estômagos foi feita sob anestesia com injeção i.p. de cloridrato de xilazina e cloridrato de ketamina (Anasedan e Dopalen, Vetbrands, Jacareí, SP, Brasil) em dose excessiva: $0,5 \mathrm{~mL} / 100 \mathrm{~g}$ de massa corpórea, $1: 1$, às $10 \mathrm{~h}$. Os estômagos foram retirados, lavados em solução salina, abertos pela menor curvatura, esticados em cortiça e submetidos aos diferentes procedimentos, de acordo com o tipo de ensaio ao qual seriam submetidos.

\subsubsection{Coletas para análises morfológicas e imuno-histoquímica}

O material coletado através do procedimento descrito acima foi fixado em formaldeído $10 \%$ por 4 horas, quando foi então seccionado em três fragmentos, cada um contendo porções de córnea, corpo e antro gástrico. Esses fragmentos foram removidos da cortiça e acomodados sobre uma esponja em um cassete plástico e o processo de fixação prosseguiu por mais 4 horas. Ao término desse período, o cassete com o material coletado foi mantido em álcool $70^{\circ}$ até ser incluído em parafina.

Para a realização das análises citadas, foram feitos cortes não seriados de $6 \mu \mathrm{m}$. As amostras que foram submetidas à imuno-histoquímica foram previamente coradas com hematoxilina e eosina (HE) para controle da qualidade do material.

\subsubsection{Coletas para RT-PCR e Western blot}

As amostras de RNA utilizadas para as reações de RT-PCR e as amostras de proteína usadas para a realização de Western blot para ghrelina e GHS-R1a foram coletadas 
previamente, para os estudos de Osaki et al. (2010, 2011). Já as amostras submetidas ao protocolo de extração de proteínas de membrana, também analisadas Western blot, foram coletadas especificamente para este estudo.

Ambas as coletas ocorreram dentro dos mesmos parâmetros já descritos. Brevemente, após a retirada, abertura e lavagem dos estômagos, os mesmos foram submetidos à raspagem para obtenção da mucosa gástrica, procedimento realizado sob microscópio estereoscópico (Zeiss, Oberkochen, Alemanha).

As amostras obtidas para a avaliação da concentração de ghrelina tecidual pelo método de Western blot foram conservadas em solução salina tamponada com Tris (TBS) 0,02 M, adicionada de fluoreto de fenilmetilsulfonil a 10\% (PMSF 0,1 M). Já o material coletado para a análise de GHS-R foi conservado sob duas formas distintas: congelado em nitrogênio líquido para realização de RT-PCR e Western blot (após fracionamento de membrana), ou em TBS 0,02 M e PMSF 0,1 M para Western blot (extração proteica total). Em ambos os casos, as amostras foram acondicionadas em freezer a $-80^{\circ} \mathrm{C}$ até seu processamento.

\subsection{Imuno-histoquímica e quantificação das células imunomarcadas}

\subsubsection{Ghrelina}

Lâminas recobertas com poli-L-lisina (Sigma-Aldrich), contendo cortes da mucosa do corpo gástrico, foram desparafinizadas e hidratadas em tampão fosfato salina (PBS 0,05 M, pH 7,4) com Triton x-100 a 0,1\% (10 min). Após a inativação da peroxidase endógena em metanol- $\mathrm{H}_{2} \mathrm{O}_{2} 3 \%$ (10 min), os cortes foram lavados com água destilada e PBS e submetidos à recuperação de antígeno, que foi realizada em pepsina 0,05\% diluída em $\mathrm{HCl} 0,1 \mathrm{~N}$ (20 min, $37{ }^{\circ} \mathrm{C}$ ). Os cortes foram novamente lavados com água destilada e PBS e posteriormente incubados com soro de cabra a 10\% diluído em solução de albumina bovina sérica (PBS-BSA 0,1\%) (20 min) à temperatura ambiente (TA), para bloquear ligações inespecíficas.

Subsequentemente a etapa de bloqueio, as lâminas foram incubadas com anticorpo policlonal de coelho para ghrelina (overnight, $4{ }^{\circ} \mathrm{C}, 1: 100$ - Phoenix Pharmaceuticals). Após lavagem com PBS, todos os cortes foram incubados com anticorpo secundário de cabra anticoelho conjugado à biotina (2 horas, TA, 1:200 - Jackson ImmunoResearch) e, em seguida, com o complexo estreptavidina biotina peroxidase (1 hora, TA, 1:200 - Jackson ImmunoResearch). A revelação foi feita com solução de diaminobenzidina (DAB) a $2 \%$ (Kit Liquid DAB + Substrate Chromogen System, Dako, Carpinteria, CA, EUA) (5 min), e 
posteriormente as lâminas foram contracoradas com Hematoxilina de Mayer a $0,1 \%$ e diferenciadas em solução saturada de carbonato de lítio. Os controles negativos das reações foram obtidos pela omissão do anticorpo primário.

A quantificação de células imunomarcadas para ghrelina foi realizada com o uso de microscópio de luz (Nikon, Tóquio, Japão), com o auxílio de ocular integradora $n^{\circ} 2$ (8x, Zeiss) e objetiva de imersão (100x), por meio da contagem do número de células positivas por campo. Foram contados de 10 a 15 campos por lâmina, selecionados ao acaso dentro de áreas íntegras, bem orientadas e com as glândulas gástricas perpendiculares à luz do estômago. Os resultados foram expressos em número de células imunomarcadas por campo para cada animal.

\subsubsection{BrdU - Determinação do Índice de síntese de DNA (IS)}

Para a avaliação do papel da ghrelina sobre a proliferação celular gástrica sob a ação do antagonista do receptor GHS-R, foram feitos ensaios de imuno-histoquímica para BrdU nos materiais coletados para os grupos DP e DPA.

Lâminas recobertas com poli-L-lisina (Sigma-Aldrich) contendo cortes da mucosa do corpo gástrico foram submetidas à desparafinização e reidratação com PBS 0,05 M (pH 7,4 10 min). Como descrito acima, após a inativação da peroxidase endógena, o material foi submetido à recuperação de antígeno com pepsina a $0,1 \%$ diluída em $\mathrm{HCl} 0,1 \mathrm{~N}(20 \mathrm{~min}$, $37^{\circ} \mathrm{C}$ ). Novas lavagens com água destilada e PBS foram feitas e os cortes foram incubados com anticorpo monoclonal para BrdU (overnight, $4{ }^{\circ} \mathrm{C}$, 1:100 - GE Healthcare, Buckinghamshire, Inglaterra), diluído em nuclease e PBS 0,05 M (1:1) e, após lavagem com PBS-BSA $0,1 \%$, receberam o anticorpo secundário anti-camundongo conjugado à peroxidase (2 horas, TA, 1:40 - Jackson ImmunoResearch).

Como já descrito na seção 4.4.1, a revelação foi feita com solução de DAB a $2 \%$ (Kit Liquid DAB + Substrate Chromogen System, Dako) (5 min), seguida de contracoloração com Hematoxilina de Mayer a 0,1\% e diferenciação em solução saturada de carbonato de lítio. Os controles negativos das reações para BrdU também foram obtidos pela omissão do anticorpo primário.

O índice de síntese de DNA (IS) foi determinado dentro do compartimento proliferativo que, na idade estudada, 18 dias de vida pós-natal, ocupa toda a extensão das glândulas gástricas (Alvares e Gama, 1993; Gama e Alvares, 2000). A análise foi realizada em microscópio de luz (Nikon), com o auxílio de ocular integradora Zeiss $n^{\circ} 2$ (8x) e objetiva 
de imersão (100x) e se deu por meio da contagem de núcleos de células epiteliais marcados e não marcados para BrdU, atingindo um total de aproximadamente 2.500 células por animal (Aherne et al., 1977). Os campos contados foram selecionados ao acaso dentro de áreas íntegras, bem orientadas e com as glândulas gástricas perpendiculares à luz do estômago.

O cálculo do índice de síntese de DNA para cada animal foi feito com base na fórmula abaixo:

$$
\text { IS }=\frac{\text { número de células marcadas }}{\text { número total de células }} \times 100
$$

\subsection{RT-PCR para $G H S-R$}

\subsubsection{Extração de RNA}

A partir de amostras obtidas pela raspagem da mucosa gástrica previamente coletadas e mantidas em nitrogênio líquido, a extração de RNA foi realizada com TRIzol (Invitrogen, Carlsberg, CA, EUA). O tecido foi macerado com homogeneizador elétrico (5 min), adicionado de $200 \mu \mathrm{L}$ de clorofórmio (Merck, Darmstadt, Alemanha) e, após agitação em vórtex (15 s), as amostras foram mantidas em gelo (3 min) para posterior centrifugação a $12.000 \mathrm{~g}\left(15 \mathrm{~min}, 4^{\circ} \mathrm{C}\right)$.

A fase aquosa superior foi retirada, $500 \mu \mathrm{L}$ de isopropanol (Merck) foram adicionados e as amostras foram acondicionadas em gelo (10 min) para, em seguida, serem novamente centrifugadas a $12.000 \mathrm{~g}\left(15 \mathrm{~min}, 4^{\circ} \mathrm{C}\right)$ com o objetivo de precipitar o RNA. O sobrenadante foi desprezado e o precipitado, após lavagem com $1 \mathrm{~mL}$ de etanol 75\% (Merck) em água DEPC (Invitrogen), foi centrifugado a $7.500 \mathrm{~g}\left(5 \mathrm{~min}, 4{ }^{\circ} \mathrm{C}\right) . \mathrm{O}$ sobrenadante foi outra vez desprezado e procedeu-se a secagem do precipitado (TA, sob fluxo laminar), que, posteriormente foi re-suspendido em água DEPC $0,1 \%$.

A quantificação do RNA foi realizada por espectrofotometria com caminho óptico de 0,2 mm (NanoVue - GE Healthcare) (Laboratório de Citofisiologia do Trofoblasto - Prof ${ }^{a}$. Dra $^{\text {a }}$ Estela M. A. F. Bevilacqua). A integridade do RNA foi testada em gel de agarose $1 \%$ com brometo de etídeo em tampão TAE (Tris acetato $40 \mathrm{mM}$ - EDTA $1 \mathrm{mM}$ ) através da observação das bandas correspondentes às subunidades $30 \mathrm{~S}$ e $50 \mathrm{~S}$ do RNA ribossomal. 


\subsubsection{Síntese de cDNA - reação da Transcriptase Reversa $(R T)$}

A partir do RNA, foi realizada a síntese de cDNA pela reação da transcriptase reversa (RT). Para tal, foram utilizados $3 \mu \mathrm{g}$ de RNA total, diluídos em água DEPC em quantidade suficiente para $10 \mu \mathrm{L}$.

A cada tubo foram adicionados $10 \mu \mathrm{L}$ de solução composta de: $2 \mu \mathrm{L}$ de Oligo (dT) Primer, $1 \mu \mathrm{L}$ de dNTP 10 mM, $2 \mu \mathrm{L}$ de DTT 0,1 M, $4 \mu \mathrm{L}$ de Tampão First-Strand 5X e $1 \mu \mathrm{L}$ de enzima SuperScript II RT (200 U/ $\mu$ L).

As amostras foram incubadas em termociclador (Eppendorf AG, Hamburg, Alemanha) nas seguintes condições: $21{ }^{\circ} \mathrm{C}$ por 10 minutos para anelamento; $42{ }^{\circ} \mathrm{C}$ por 50 minutos para atuação da enzima de transcrição; $70{ }^{\circ} \mathrm{C}$ por 10 minutos para inativação desta enzima; $4{ }^{\circ} \mathrm{C}$ para resfriamento e posterior acondicionamento em freezer a $-20{ }^{\circ} \mathrm{C}$.

A fim de confirmar a eficiência da síntese de cDNA, alíquotas de $1 \mu \mathrm{L}$ foram diluídas em tampão de amostra Blue Juice $5 \mathrm{X}$, aquecidas $\left(10 \mathrm{~min}, 70^{\circ} \mathrm{C}\right)$ e o cDNA foi separado em gel de agarose $1 \%$ contendo brometo de etídeo (50 min, 90V). Todos os reagentes utilizados nas etapas descritas eram da marca Invitrogen.

\subsubsection{Amplificação do DNA - Reação em cadeia da polimerase (PCR)}

Para realização da reação de amplificação (PCR), foram adicionadas alíquotas de $1 \mu \mathrm{L}$ de cDNA de cada uma das amostras a uma mistura previamente preparada contendo $2,0 \mu \mathrm{L}$ de Tampão PCR 10X (pH 8,4), 0,4 $\mu \mathrm{L}$ de dNTP $10 \mathrm{mM}, 0,6 \mu \mathrm{L}$ de $\mathrm{MgCl} 250 \mathrm{mM}$ (todos da marca Invitrogen), 0,5 $\mu \mathrm{L}$ de oligonucleotídeo iniciador sense, $0,5 \mu \mathrm{L}$ de oligonucleotídeo iniciador anti-sense (Tabela 2) e 14,8 $\mu \mathrm{L}$ de água MilliQ autoclavada. Seguiu-se um aquecimento de $95^{\circ} \mathrm{C}$ por 5 minutos.

Os oligonucleotídeos iniciadores para $G H S$-R e para $\beta$-actina, utilizada como controle interno, foram desenhados através do programa de domínio público Primer3 (Rozen e Skaletsky, 1998) e sintetizados pela empresa IDT (Iowa, EUA). Em seguida, foram adicionados $0,2 \mu \mathrm{L}$ de Taq DNA polimerase $5 \mathrm{U} / \mu \mathrm{L}$ (Invitrogen) à solução, que foi então incubada a $94{ }^{\circ} \mathrm{C}$ por 3 minutos, seguida de 37 ciclos de: desnaturação a $94{ }^{\circ} \mathrm{C}$ por 30 segundos, anelamento a $55^{\circ} \mathrm{C}$ por 30 segundos e extensão a $72{ }^{\circ} \mathrm{C}$ por 30 segundos e por fim, ocorreu a extensão final a $72{ }^{\circ} \mathrm{C}$ por 10 minutos.

Após diluição em $5 \mu \mathrm{L}$ de Tampão de Corrida Blue Juice 5X (Invitrogen), $10 \mu \mathrm{L}$ de cada uma das amostras foram corridos em gel de agarose 1\% em TAE. Os géis foram 
analisados por meio de trans-iluminação com luz ultravioleta (UV transilluminator, BioDoc-it Imaging System, UVP, Upland, CA, EUA) (Laboratório de Biologia Celular da Glândula Mamária - Prof $^{\mathrm{a}}$. Dra ${ }^{\mathrm{a}}$. Nathalie Cella) e a densidade óptica integrada (IOD) das bandas correspondentes foi analisada utilizando o programa de domínio público Image $\mathbf{J}(1.37 \mathrm{v}$ Software, National Institute of Mental Health, NIH, EUA). Os resultados foram expressos como a relação entre a IOD de $G H S$ - $R$ e de $\beta$-actina correspondente.

Tabela 2 - Sequência dos oligonucleotídeos iniciadores utilizados para a realização de RT-PCR

\begin{tabular}{ccc}
\hline Proteína & Oligonucleotídeo iniciador sense & Oligonucleotídeo iniciador anti-sense \\
\hline GHS- $R$ & 5'-TCAGCCAGTACTGCAACC-3' & 5'-TGTAGAGCAATGAGCGAT-3' \\
$\beta$-actina & 5'-GTCGTACCACTGGCATTGTG-3' & 5'-TGCCGATAGTGATGACCTGA-3' \\
\hline
\end{tabular}

FONTE: Bittar-Rodrigues (2012).

\subsection{Western blot}

A extração proteica das amostras analisadas para ghrelina foi realizada por homogeneização em tampão RIPA ( $\mathrm{NaCl} 150$ mM; NP-40 1\%; ácido deoxicolato de sódio 1\% em Tris- $\mathrm{HCl} 50 \mathrm{mM}$ ) associado a inibidores de protease e fosfatase (PMSF 0,1 M, leupeptina 0,1 M, aprotinina $0,1 \mathrm{M}$, ortovanadato de sódio $5 \mathrm{mM}$ e $15 \mathrm{mg} / \mathrm{mL}$ de benzamidina). Em seguida, as amostras foram centrifugadas a $12.000 \mathrm{~g}\left(5 \mathrm{~min}, 4{ }^{\circ} \mathrm{C}\right)$ e o sobrenadante foi coletado e acondicionado em freezer a $-80{ }^{\circ} \mathrm{C}$.

O conteúdo proteico de GHS-R na mucosa gástrica foi estudado de duas maneiras distintas: extração total de proteínas, como descrito acima, e extração de proteínas de membrana, visto que o GHS-R é um receptor acoplado à proteína G (GPCR) (Howard et al., 1996). Neste caso, a extração proteica foi realizada em três etapas distintas, como segue:

Etapa 1: homogeneização em solução contendo Tris-HCl 50 mM (pH 7,4), EDTA 1 $\mathrm{mM}$ e sacarose $10 \%$ adicionada dos inibidores de protease (PMSF 0,1 M, leupeptina 0,1 M e aprotinina $0,1 \mathrm{M})$, seguida de centrifugação a $20.817 \mathrm{~g}\left(15 \mathrm{~min}, 4^{\circ} \mathrm{C}\right)$ e posterior remoção e descarte do sobrenadante.

Etapa 2: re-suspensão do precipitado em solução de Tris- $\mathrm{HCl} 50 \mathrm{mM}(\mathrm{pH} \mathrm{7,4)} \mathrm{e}$ EDTA $1 \mathrm{mM}$ com um subsequente período incubação em gelo (30 min) e posterior centrifugação a $20.817 \mathrm{~g}\left(25 \mathrm{~min}, 4{ }^{\circ} \mathrm{C}\right)$. Novamente o sobrenadante foi removido e descartado. 
Etapa 3: re-suspensão do precipitado em Tris- $\mathrm{HCl} 50 \mathrm{mM}(\mathrm{pH} 7,4)$ em um volume pequeno o suficiente para garantir a homogeneidade da suspensão. As amostras foram então mantidas em freezer a $-80^{\circ} \mathrm{C}$.

A quantificação de proteínas para os dois tipos de extração empregados foi feita de acordo com o método de Bradford (1976). Para garantir a homogeneidade das amostras após a extração fracionada, todos os tubos foram sonicados, sendo submetidos a 4 pulsos de $5 \mathrm{~s}$ a $30 \%$ de amplitude (processador ultrassônico Vibra-Cell VCX 130, Sonics \& Materials Inc., Newtown, CT, EUA - Laboratório de Biologia do Desenvolvimento de Insetos - Prof. Dr. Fábio Siviero).

O fracionamento de proteínas, tanto para o estudo de ghrelina quanto para o estudo de GHS-R, iniciou-se com a diluição das amostras em tampão (Tris 0,5 M, glicerol 17\%, SDS $1,7 \%$, Bromophenol Blue $0,04 \%$ e $\beta$-mercaptoetanol $1 \%$ ) e aquecimento a $100{ }^{\circ} \mathrm{C}$ (5 min).

Posteriormente, $30 \mu \mathrm{g}$ de proteína foram distribuídos em cada poço de um gel de poliacrilamida-SDS em gradiente 5\% a 20\% (Gradient Maker SG30, Hoefer, Holliston, MA, EUA) para a análise de ghrelina e a $12 \%$ para GHS-R. Em um protocolo diferenciado, na tentativa de identificar o GHS-R1a com o uso de um anticorpo específico (Phoenix Pharmaceuticals), $60 \mu \mathrm{g}$ de proteína foram distribuídos nos poços de um gel de poliacrilamida-SDS em gradiente 5\% a 20\%. Seguiu-se então a eletroforese (3 h, TA, $100 \mathrm{~V}$, $50 \mathrm{~mA}$ ) em tampão de corrida (Tris 0,025 M, glicina 0,192 M e SDS 0,1\%).

Subsequentemente, as proteínas fracionadas foram transferidas para uma membrana de nitrocelulose (Hybond ECL, GE Healthcare) em tampão de transferência (Tris 0,025 M, glicina 0,192 M e metanol a 20\%). Para a detecção de ghrelina e de GHS-R1a, os parâmetros utilizados foram: $2 \mathrm{~h}, 4{ }^{\circ} \mathrm{C}$, voltagem de $100 \mathrm{~V}$ e corrente de $200 \mathrm{~mA}$. Já para a análise de GHS-R foram: overnight, $4{ }^{\circ} \mathrm{C}$, voltagem de $25 \mathrm{~V}, 200 \mathrm{~mA}$. Finalmente, procedeu-se a coloração das membranas em solução de Ponceau 0,5\% (3 min), para a checagem do procedimento de transferência, e depois a lavagem em TBS 0,02 M (10 min). As principais características em relação ao fracionamento de proteínas para o estudo de ghrelina, GHS-R1a e GHS-R encontram-se resumidas na Tabela 3. 
Tabela 3 - Parâmetros relativos ao fracionamento de proteínas para o estudo de ghrelina, GHS-R1a e GHS-R

\begin{tabular}{ccccc}
\hline Proteína & Extração proteica & Gel de corrida & $\begin{array}{c}\text { Carregamento } \\
\text { de proteína }\end{array}$ & Transferência \\
\hline Ghrelina & Total & Gradiente 5\% a $20 \%$ & $30 \mu \mathrm{g} /$ amostra & 2 horas \\
GHS-R1a & Total & Gradiente 5\% a $20 \%$ & $60 \mu \mathrm{g} /$ amostra & 2 horas \\
GHS-R & Proteína de membrana & $12 \%$ & $30 \mu \mathrm{g} /$ amostra & overnight \\
\hline
\end{tabular}

FONTE: Bittar-Rodrigues (2012).

\subsubsection{Immunoblot}

O immunoblot iniciou-se com o bloqueio de ligações inespecíficas com uma solução de TBS 0,02 M e Tween 20 (0,1\%) (TTBS) acrescida de leite em pó desnatado a 5\% (Molico, Nestlé, Brasil) (1 h, TA, sob agitação). Após lavagem com TTBS, foi feita a incubação com os anticorpos primários listados na Tabela 4 , todas a $4^{\circ} \mathrm{C}$ e sob agitação. Após sucessivas lavagens com TBS e TTBS, as membranas foram incubadas com anticorpo secundário anticoelho ou anti-camundongo conjugados a peroxidase $(1 \mathrm{~h}$, TA, sob agitação, 1:1000 para o primeiro e 1:500 para o segundo - GE Healthcare) diluídos em solução de TTBS e leite em pó desnatado a 5\% (Molico).

Após novas lavagens com TBS e TTBS, a reação foi revelada com o kit ECL (GE Healthcare) em filmes radiográficos (MXG-Plus, Kodak, São Paulo, SP, Brasil), que foram digitalizados e, posteriormente, a IOD das bandas foi analisada através do programa de domínio público Image J. Os resultados foram expressos como a relação entre a IOD das proteínas estudadas e a IOD obtida para a $\beta$-actina correspondente, utilizada como controle interno de carregamento de proteínas.

Tabela 4 - Anticorpos primários utilizados para immunoblot

\begin{tabular}{ccccc}
\hline Anticorpo & Fabricante & Diluição & Veículo & Incubação \\
\hline Ghrelina & Phoenix Pharmaceuticals & $1: 500$ & TTBS + leite 5\% & overnight \\
GHS-R1a & Phoenix Pharmaceuticals & $1: 500$ & TTBS + leite 5\% & 60 horas \\
GHS-R & Proteimax (Cotia, SP, Brasil) & $1: 250$ & TTBS & 44 horas \\
B-actina & Sigma-Aldrich & $1: 10000$ & TTBS + leite 5\% & overnight \\
\hline
\end{tabular}

FONTE: Bittar-Rodrigues (2012). 


\subsection{Análise estatística}

Os resultados obtidos foram agrupados de acordo com o padrão alimentar e tratamento. Para a análise realizada entre dois grupos apenas foi utilizado o teste $t$ de Student. Quando mais de dois grupos foram analisados, a avaliação se deu por meio de análise de variância (ANOVA), seguida pelo teste de comparações múltiplas de Tukey. A significância foi estabelecida em $\mathrm{p}<0,05$ para todos os testes realizados. As análises foram realizadas com o pacote estatístico GraphPad Prism 5 (GraphPad Software, Inc., San Diego, CA, EUA).

\subsection{Esquema dos procedimentos}

A Figura 4 resume o procedimento experimental para os animais em desmame precoce e os tratamentos com o antagonista [D-Lys-3]-GHRP-6, bem como indica os grupos de animais, os dias e respectivos horários das coletas realizadas para as diferentes técnicas utilizadas nesse estudo.

Figura 4 - Esquema de procedimentos e coletas.

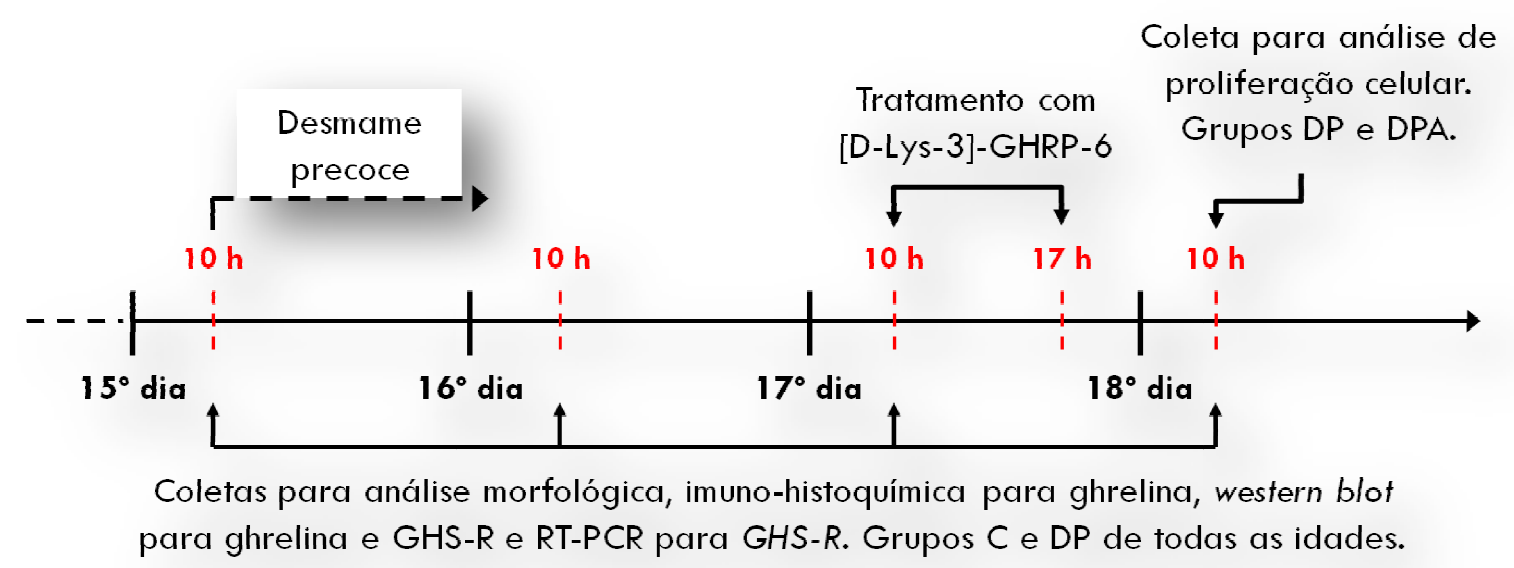

FONTE: Bittar-Rodrigues (2012). 


\section{RESULTADOS}

\subsection{Massa corpórea dos animais}

A massa corpórea dos animais foi monitorada durante o período de desmame precoce, visto que essa condição representa uma situação de estresse na qual tanto a ausência materna quanto a alteração do padrão alimentar podem favorecer sua redução (Gama e Alvares, 2000; Lin et al., 1998, 2001).

Os animais do grupo C apresentaram ganho de massa diariamente, o que é compatível com o crescimento normal (Figura 5). Ao contrário, os animais desmamados precocemente grupo DP - tiveram redução de massa corpórea, que se destaca no $17^{\circ}$ dia de vida $(\mathrm{p}<0,05)$. Embora tenha havido um sutil aumento da massa corpórea no $18^{\circ}$ dia, evidenciando uma tendência à recuperação, os animais DP apresentaram massa corpórea aproximadamente 30\% menor em relação aos animais $\mathrm{C}$ ao término do tratamento.

Figura 5 - Massa corpórea dos animais dos grupos controle (C) e desmame precoce (DP) do $15^{\circ}$ ao $18^{\circ}$ dia de vida pós-natal. As medidas apresentadas foram realizadas antes da eutanásia. Cada barra representa a média \pm desvio padrão para os grupos avaliados. $(\mathrm{n})=$ número de animais por grupo. Os resultados foram analisados por ANOVA seguido de teste de Tukey. $\left.{ }^{*}\right) \mathrm{p}<0,05$ em relação ao grupo controle da mesma idade. (\#) $\mathrm{p}<0,05$ quando comparado com animais do mesmo grupo de tratamento na idade anterior.

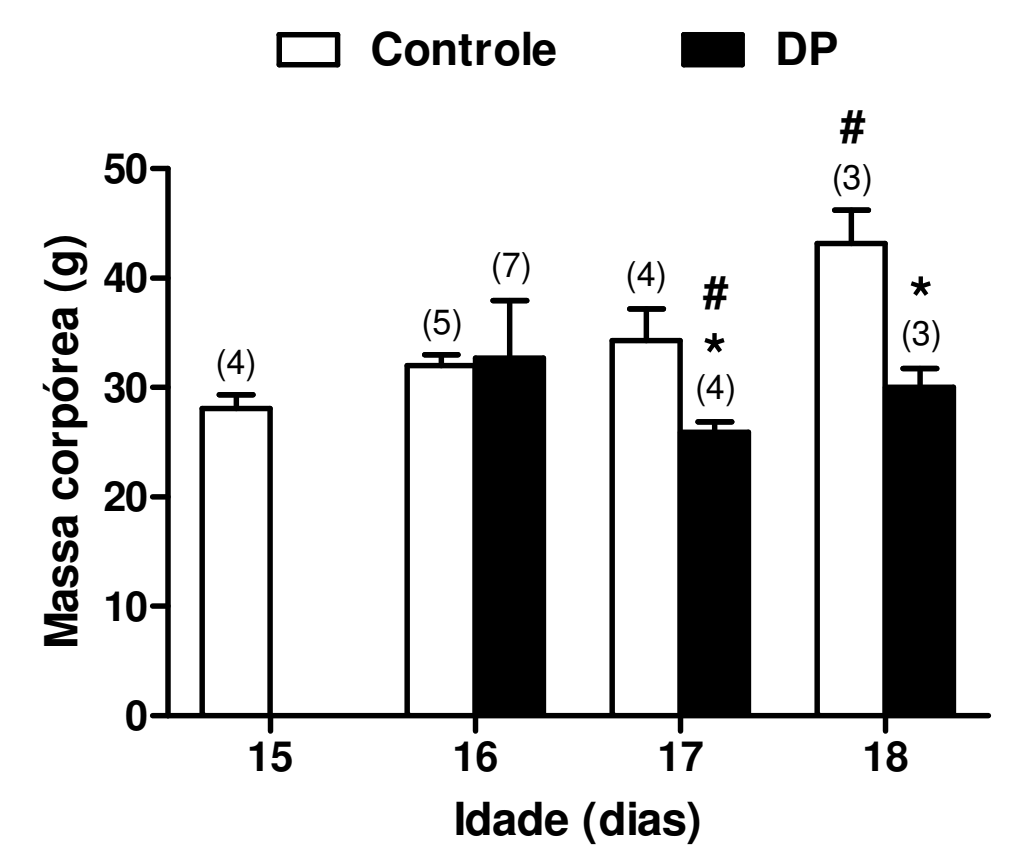


Os animais desmamados precocemente tinham acesso à pasta de ração 24 horas/dia, entretanto no primeiro dia de tratamento não se alimentavam sozinhos, o que fez com que grande parte da ingestão alimentar ocorresse nos horários em que o alimento era oferecido através de pipeta, ou seja, no momento da manipulação dos animais. A partir do $16^{\circ}$ dia, os filhotes começaram a se alimentar espontaneamente e, após a redução significativa de massa corpórea observada no $17^{\circ}$ dia, notou-se um princípio de recuperação, que pode ser observado no $18^{\circ}$ dia (Figura 5).

Para a avaliação da ação da ghrelina no processo proliferativo, foi utilizado o antagonista do receptor GHS-R, [D-Lys-3]-GHRP-6. Os animais do grupo DPA foram tratados com essa droga no $17^{\circ}$ dia, sempre após a oferta de alimento, e não houve diferença significativa de massa corpórea entre os animais do grupo DP (média de 27,18 g \pm 2,96) e os do grupo DPA (média de $28,60 \mathrm{~g} \pm 2,60$ ) no $18^{\circ}$ dia.

\subsection{Efeito do desmame precoce sobre a ghrelina gástrica}

A distribuição das células secretoras de ghrelina no estômago de animais submetidos ou não ao desmame precoce foi estudada por meio de imuno-histoquímica.

Inicialmente, o principal foco de análise foi o perfil de distribuição da ghrelina no estômago em termos de ontogênese do epitélio gástrico. Assim, nota-se que, no período estudado, o número de células imunomarcadas para ghrelina variou pouco nos animais do grupo $\mathrm{C}$, a não ser por um pico observado no $16^{\circ}$ dia $(\mathrm{p}<0,05)$ (Figura 6B, I).

Entretanto, o desmame precoce provocou alterações nesse quadro (Figura 6I): no $16^{\circ} \mathrm{e}$ $17^{\circ}$ dias a modificação do padrão alimentar resultou na redução da população de células imunomarcadas para ghrelina no grupo DP $(\mathrm{p}<0,05)$ (Figura 6C, F), enquanto que, aos 18 dias de vida pós-natal, essa situação se inverteu, com um aumento significativo $(\mathrm{p}<0,05)$ da população de células estudadas (Figura 6H).

Enquanto o desmame precoce aumentou a população de células secretoras de ghrelina do $17^{\circ}$ para o $18^{\circ}$ dia de vida $(\mathrm{p}<0,05)$ (Figura 6I), esse tratamento não alterou a localização das células imunomarcadas na glândula gástrica, já que as células "X/A-like" encontram-se principalmente na região basal da glândula (Helander, 1981; Karam e Leblond, 1993d) tanto em animais amamentados quanto submetidos ao DP (Figura 6A-H).

Após a identificação do padrão de distribuição das células secretoras de ghrelina na mucosa do estômago, foi realizada a detecção da ghrelina no extrato proteico total obtido por meio da raspagem da mucosa gástrica. $\mathrm{O}$ uso da técnica de immunoblot permitiu detectar que 
os níveis de ghrelina tecidual acompanharam os resultados obtidos por imuno-histoquímica (Figura 6J), de forma que a concentração ficou praticamente estável nos animais do grupo C, reduzida nos animais DP no $16^{\circ}$ e $17^{\circ}$ dias, e levemente aumentada no $18^{\circ}$ dia de vida pósnatal. 
Figura 6 - Distribuição das células secretoras de ghrelina na mucosa gástrica de ratos do $15^{\circ}$ ao $18^{\circ}$ dia de vida pós-natal submetidos ou não ao desmame precoce (A-H). Fotomicrografias de reações imuno-histoquímicas para ghrelina no grupo controle aos 15 (A), 16 (B), 17 (E) e $18(\mathrm{G})$ dias de vida pós-natal, e no grupo DP aos $16(\mathrm{C}), 17(\mathrm{~F})$ e $18(\mathrm{H})$ dias de vida pósnatal. (D) Controle negativo da reação. Aumentos originais: 10x (B-H), 20x (A), 50x (detalhe na figura $\mathrm{H}$ ). Número de células marcadas para ghrelina no epitélio gástrico (I) e conteúdo proteico de ghrelina na mucosa do estômago (J) em ratos do $15^{\circ}$ ao $18^{\circ}$ dia de vida pós-natal nos grupos controle (C) e desmame precoce (DP). As bandas mostradas são representativas de cada grupo de tratamento para as respectivas idades. O gráfico apresenta a densidade óptica integrada (IOD) normalizada com os resultados de $\beta$-actina e analisada em relação ao controle do início do experimento, aos 15 dias. Cada barra representa a média \pm desvio padrão para os grupos avaliados. $(\mathrm{n})=$ número de animais por grupo. Os resultados foram analisados por ANOVA seguido de teste de Tukey. $(*) \mathrm{p}<0,05$ em relação ao grupo controle da mesma idade. (\#) $\mathrm{p}<0,05$ quando comparado com animais do mesmo grupo de tratamento com idade anterior. 


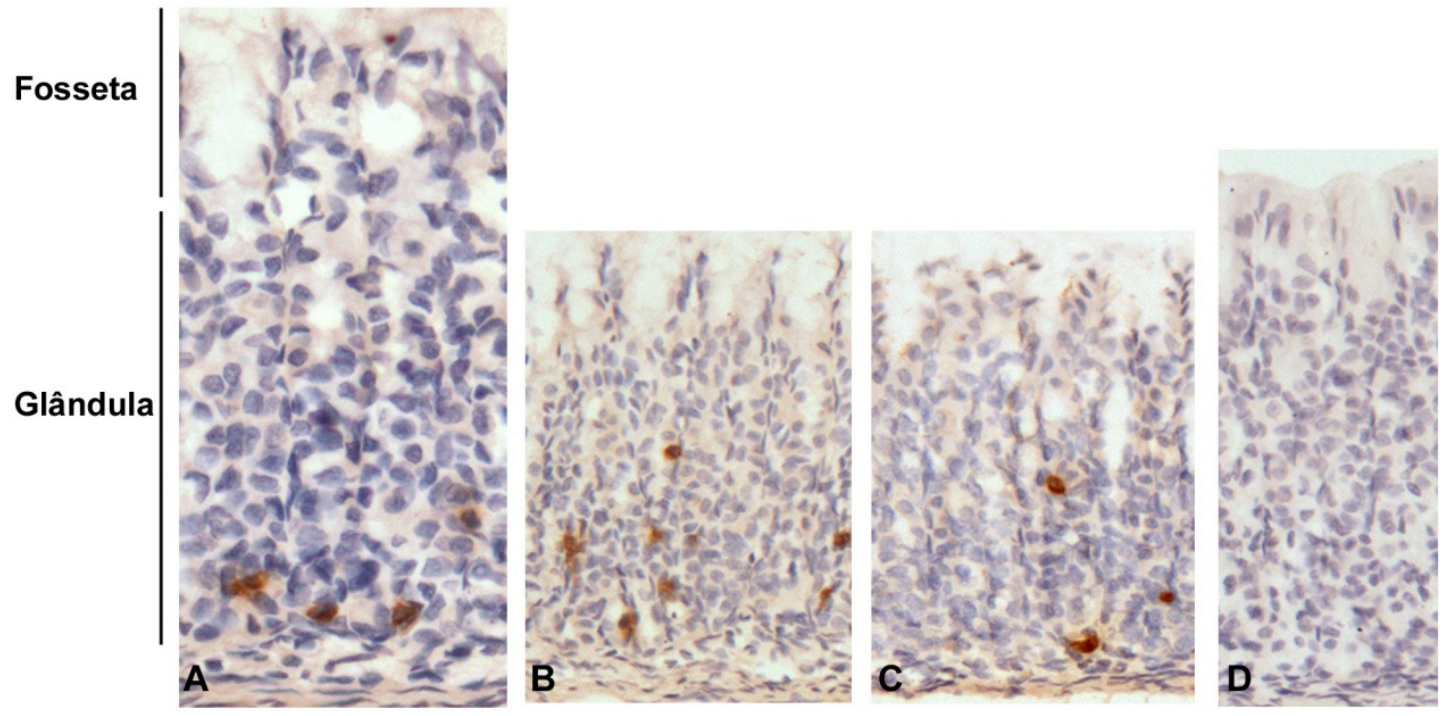

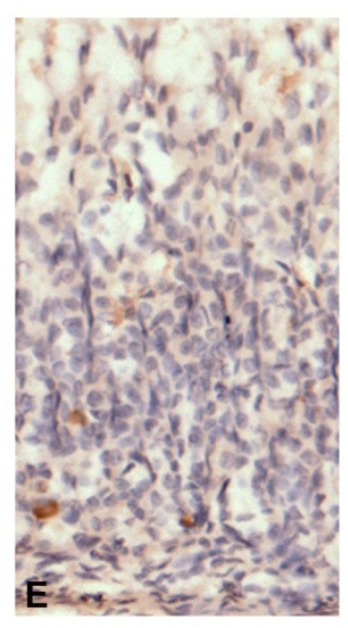

I

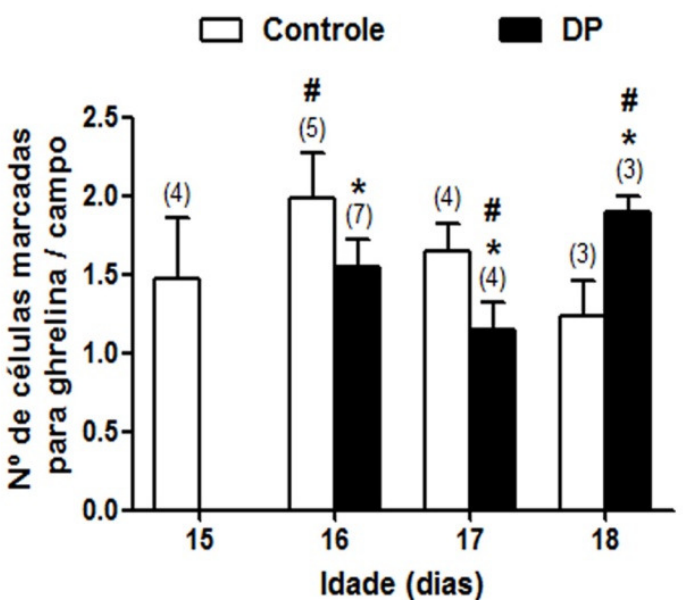

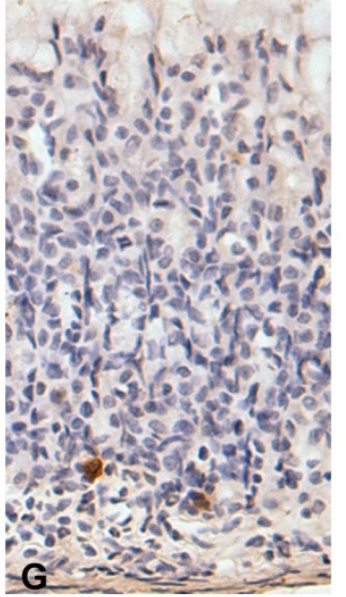

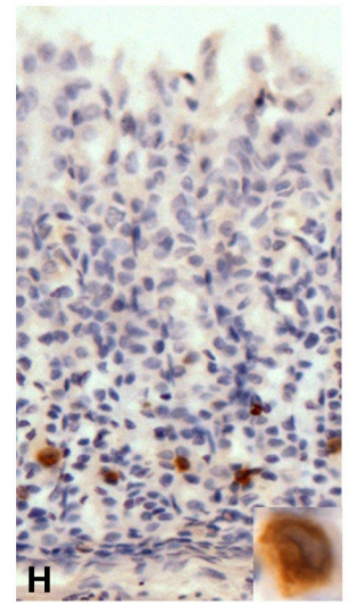

\section{J}
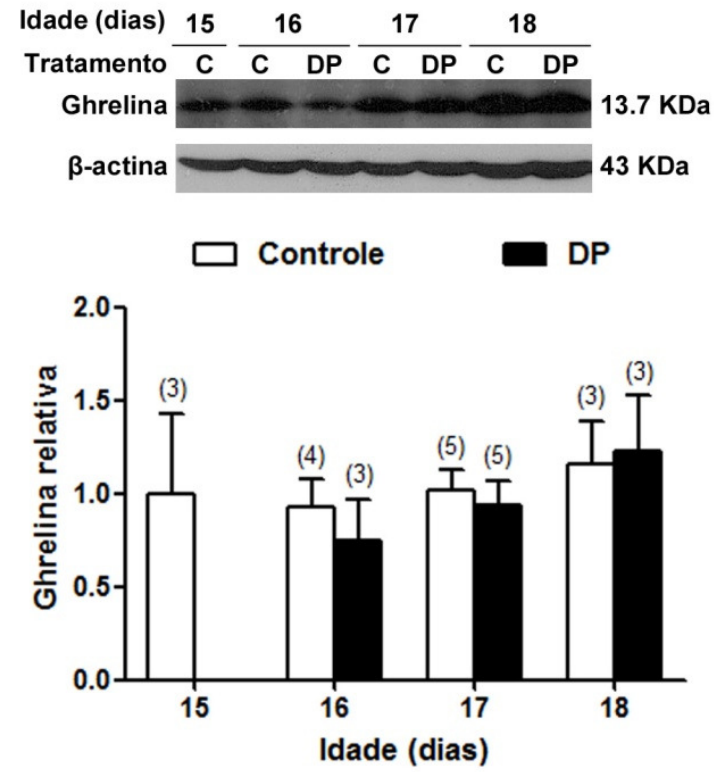


\subsection{Efeito do desmame precoce sobre a expressão gástrica do receptor GHS-R}

A avaliação da expressão do receptor de ghrelina (GHS-R) na mucosa gástrica foi realizada através das técnicas de RT-PCR e Western blot.

Os resultados obtidos por meio do RT-PCR (Figura 7A) revelaram que nos animais amamentados houve um aumento de expressão de $G H S-R$ no $16^{\circ}$ dia, que diminuiu gradativamente até que, aos 18 dias, os níveis se aproximaram do $15^{\circ}$ dia. $\mathrm{O}$ desmame precoce modificou o perfil e acarretou uma redução não significativa nos níveis de RNAm em relação ao grupo C no $16^{\circ}$ e $17^{\circ}$ dias de vida pós-natal. Seguiu-se então a inversão desta condição no $18^{\circ}$ dia, ou seja, o grupo DP apresentou maiores níveis de RNAm para o receptor, embora esta elevação não seja significativa estatisticamente.

Para a identificação da proteína gerada pelo RNAm do $G H S$-R foi utilizado o Western blot. Como mencionado anteriormente, o GHS-R apresenta-se sob duas formas denominadas 1a e 1b, porém apenas o GHS-R1a é capaz de ligar-se à ghrelina e permitir que esta execute suas funções clássicas, enquanto o subtipo GHS-R1b, sintetizado através de splicing alternativo, resulta em uma forma truncada (Howard et al., 1996; Kojima e Kangawa, 2005; McKee et al., 1997).

Com o objetivo de identificar o subtipo funcional do GHS-R, GHS-R1a, o immunoblot foi realizado com um anticorpo específico para a detecção da isoforma 1a do receptor (Phoenix Pharmaceuticals). A Figura 7B apresenta o resultado obtido para a análise de GHSR1a no extrato proteico total da mucosa gástrica de ratos do $15^{\circ}$ ao $18^{\circ}$ dia de vida pós-natal para ambos os grupos de tratamento, C e DP. Entretanto, os resultados obtidos não se mostraram reprodutíveis na sequência de experimentos, fato que encontra respaldo na literatura, devido à dificuldade de se localizar o receptor GHS-R através de Western blot (McGirr et al., 2011; Ueberberg et al., 2009).

Deste modo, restringiu-se o foco da análise da proteína GHS-R, para a idade de 18 dias de vida pós-natal, visto que o RT-PCR revelou maiores níveis de RNAm para o grupo DP frente ao $\mathrm{C}$ e que nessa idade foi detectado o aumento da população de células que sintetiza ghrelina por meio de imuno-histoquímica. Assim, a partir de um protocolo de extração de membrana, onde se localiza o receptor do tipo GHS-R, um GPCR (Howard et al., 1996), realizou-se immunoblot para os grupos C e DP na idade de 18 dias e os resultados obtidos confirmaram os achados anteriores (Figura 7C): o desmame precoce induziu um aumento na concentração de GHS-R, embora não seja significativo estatisticamente. 
Figura 7 - Expressão de GHS-R na mucosa gástrica de ratos do $15^{\circ}$ ao $18^{\circ}$ dia de vida pós-natal submetidos ou não ao desmame precoce. (A) Expressão de $G H S$ - $R$ detectada por meio de RT-PCR nos grupos controle (C) e desmame precoce (DP). As bandas são representativas de cada condição e idade. Os resultados foram analisados por ANOVA seguido de teste de Tukey. (B) Avaliação do conteúdo proteico de GHS-R1a na mucosa gástrica de ratos do $15^{\circ}$ ao $18^{\circ}$ dia de vida pós-natal nos grupos $\mathrm{C}$ e DP após extração proteica total. Foi utilizada uma amostra de um animal adulto como controle positivo da reação. (C) Avaliação de GHS-R na mucosa gástrica de ratos aos 18 dias de vida pós-natal dos grupos C e DP após extração com fracionamento de membrana. As bandas são representativas de cada condição na referida idade. Os resultados foram analisados por teste $t$ de Student monocaudal com intervalo de confiança de $95 \%$. Os gráficos (A e C) apresentam a Densidade Óptica Integrada (IOD) normalizada com os resultados de $\beta$-actina e analisada em relação ao controle do experimento: grupo no início do tratamento, aos 15 dias (A) e grupo controle aos 18 dias (C). Cada barra representa a média \pm desvio padrão para os grupos avaliados. $(\mathrm{n})=$ número de animais por grupo. (\#) $\mathrm{p}<0,05$ quando comparado com animais do mesmo grupo de tratamento com idade anterior. 
A
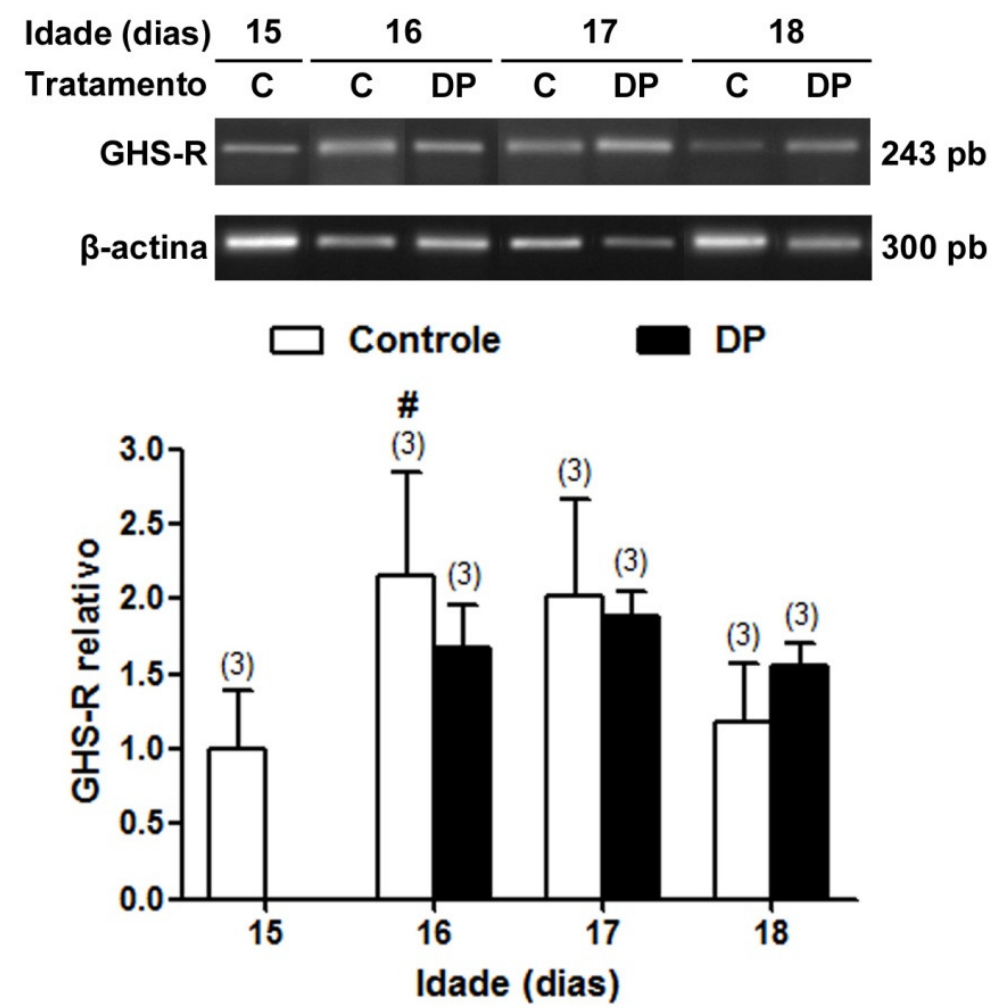

B

\begin{tabular}{|c|c|c|c|c|c|c|c|c|}
\hline$a d e$ & 15 & & & & 7 & & 8 & Adulto \\
\hline & C & C & DP & C & DP & C & DP & C \\
\hline & 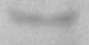 & $=$ & & +0 & $=$ & - & $=$ & - \\
\hline
\end{tabular}

C

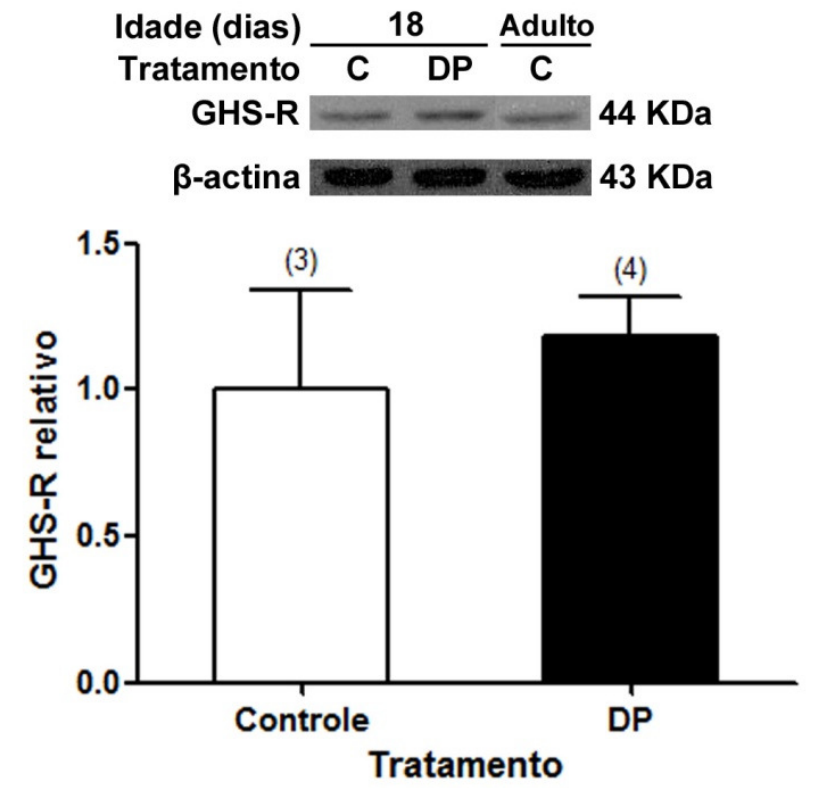




\subsection{Efeito da ghrelina sobre a proliferação da mucosa gástrica}

Sabe-se que o desmame precoce favorece a proliferação celular no epitélio gástrico (Gama e Alvares, 2000; Osaki et al., 2011). Deste modo, a influência da ghrelina no processo proliferativo da mucosa gástrica em animais desmamados precocemente foi avaliada por meio do uso do antagonista do receptor GHS-R, [D-Lys-3]-GHRP-6, associado ao índice de síntese de DNA por incorporação de BrdU (IS).

O IS foi calculado em três condições distintas: desmame precoce (DP), desmame precoce tratado com antagonista em duas doses de $5 \mu \mathrm{g} / \mathrm{g}$ de massa corpórea (DPA - [5]) e desmame precoce tratado com antagonista em duas doses de $10 \mu \mathrm{g} / \mathrm{g}$ de massa corpórea (DPA - [10]). O tratamento realizado no grupo DPA - [5] reduziu significativamente $(\mathrm{p}<0,05)$ o IS deste grupo (Figura 8B, H), tanto em relação ao grupo DP, quanto em relação ao grupo DPA - [10], que mostraram um IS muito similar entre si (Figura 8A, C, H). 
Figura 8 - Avaliação da proliferação celular na mucosa gástrica de ratos com 18 dias de vida pósnatal submetidos ao desmame precoce e tratados (DPA - [5], DPA - [10]) ou não (DP) com o antagonista [D-Lys-3]-GHRP-6. Fotomicrografias de reações imuno-histoquímicas para BrdU em animais DP (A, E), DPA - [5] (B, F) e DPA - [10] (C, G). (D) Controle negativo da reação. Aumentos originais: 10x (A-D) e 50x (E-G). (H) Índice de síntese (IS) de DNA nas células epiteliais gástricas. Cada barra representa a média \pm desvio padrão para os grupos avaliados. $(n)=$ número de animais por grupo. Os resultados foram analisados por ANOVA seguido de teste de Tukey. (*) $\mathrm{p}<0,05$ em relação ao grupo DP. (\#) $\mathrm{p}<0,05$ quando comparado com animais do grupo DPA $-[5]$.
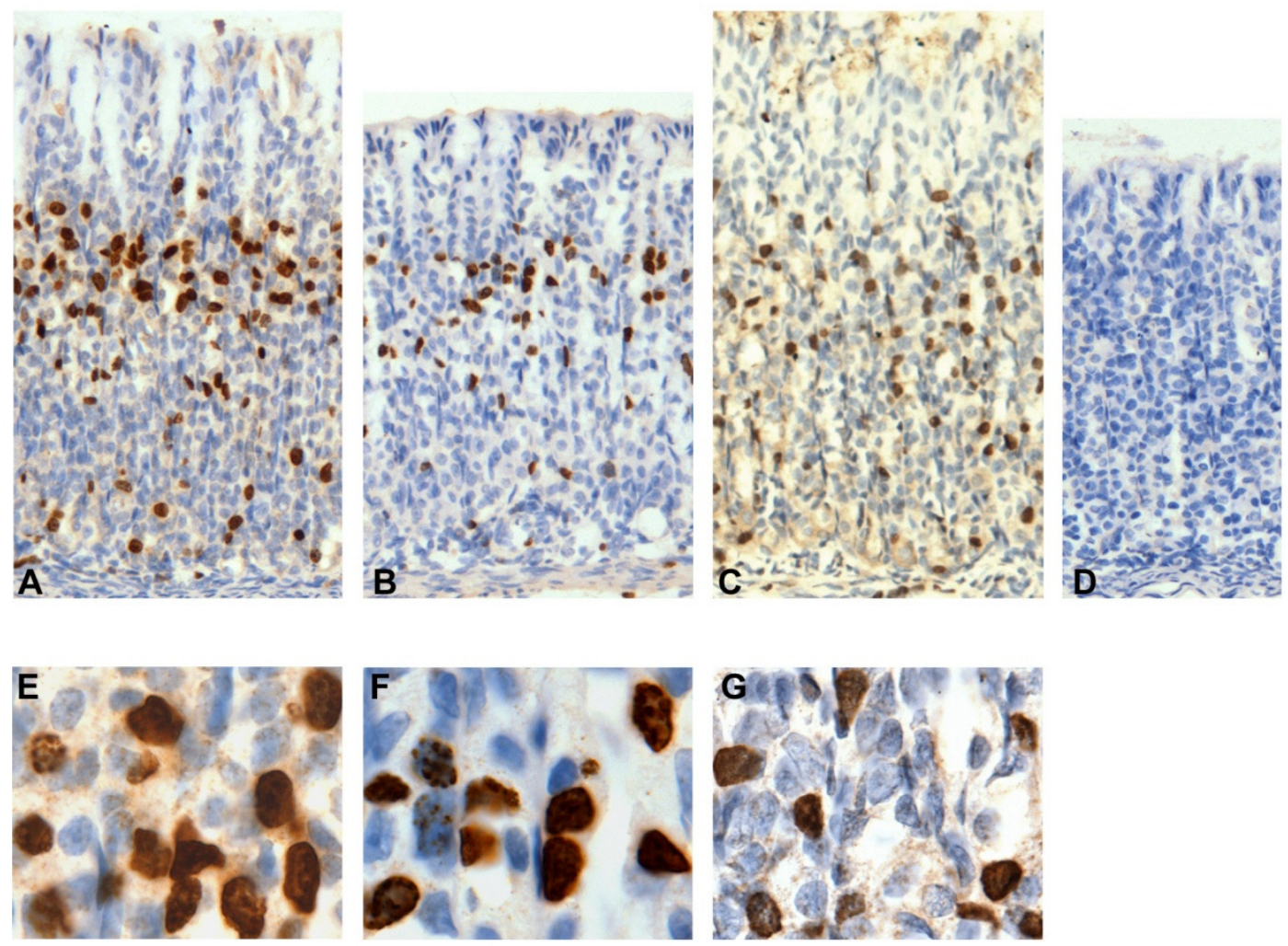

H

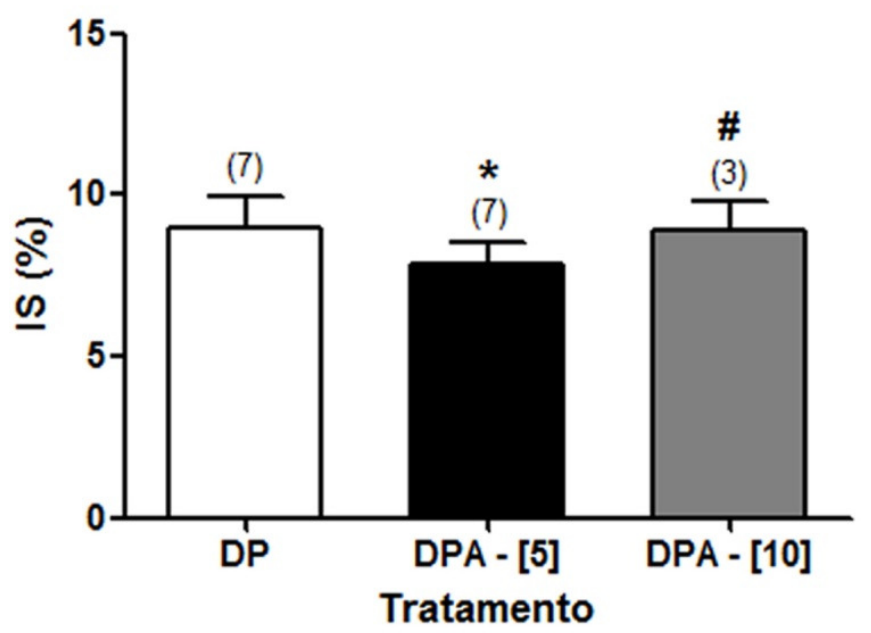




\section{DISCUSSÃO}

O período de transição alimentar no qual ocorre o desmame é crítico para o crescimento do trato gastrintestinal e o desmame precoce pode desencadear uma série de alterações morfológicas e fisiológicas que podem modificar o desenvolvimento normal e até reprogramar funções na vida adulta. Ao considerarmos estes fatos e a relevância da ghrelina para a ingestão alimentar, homeostase energética e controle do crescimento, no presente trabalho investigamos a influência do desmame precoce na expressão gástrica de ghrelina e de seu receptor GHS-R, além do papel deste hormônio na proliferação celular do estômago.

Uma das consequências imediatas do desmame precoce é a redução da massa corpórea dos animais submetidos a este padrão alimentar, que se reflete na diminuição da velocidade de crescimento quando comparada a dos animais amamentados normalmente (Boyle e Koldovský, 1980; Gama e Alvares, 2000; Lin et al., 1998, 2001; Osaki et al., 2010). O acompanhamento da evolução desse parâmetro no nosso estudo revelou que os animais $\mathrm{C}$ apresentaram ganho de massa corpórea diário, como esperado para a terceira semana de vida pós-natal, enquanto o desmame precoce modificou o padrão de crescimento, com uma significativa queda observada no $17^{\circ}$ dia de vida pós-natal.

Outros estudos mostraram uma diminuição logo após o primeiro dia de tratamento, ou seja, a partir do $16^{\circ}$ dia de vida pós-natal (Gama e Alvares, 2000; Lin et al., 1998, 2001; Osaki et al., 2010). Nossos resultados revelaram que no $16^{\circ}$ dia, os animais DP ainda não apresentavam alterações na massa corpórea, indicando inclusive uma tênue elevação frente aos animais C. Como a separação dos animais que compuseram os grupos experimentais C e DP foi realizada de maneira aleatória, possivelmente alguns filhotes do grupo DP iniciaram o tratamento com massa maior que os $\mathrm{C}$, e isto pode ter contribuído para que o efeito fosse detectado somente no $17^{\circ}$ dia. Entretanto, este fato não comprometeu a evolução esperada para este parâmetro, visto que no $18^{\circ}$ dia de vida pós-natal, os animais DP tiveram leve aumento de peso, revelando uma tendência à recuperação, como é relatado nos demais estudos (Gama e Alvares, 2000; Lin et al., 1998, 2001). A independência adquirida para a alimentação a partir do $17^{\circ}$ dia provavelmente contribuiu para este fato. Sabe-se que aos 14 dias de vida pós-natal, os olhos dos ratos se abrem e, aos 17 dias, os filhotes começam a desenvolver o paladar e os dentes incisivos crescem, funções que favorecem o início da alimentação espontânea (Henning, 1981), seja sob a forma de pasta ou pellet de ração.

Além dos parâmetros avaliados, notamos também que os filhotes do grupo DP eram sempre encontrados aglomerados, aninhados uns por cima dos outros, possivelmente para 
auxiliar na regulação termogênica, que, como mencionado anteriormente, também ocorre paralelamente ao processo de desmame (Henning, 1981).

Conforme discutido, os animais desmamados precocemente tendem a recuperar a massa perdida durante o tratamento, o que revela que o atraso observado no crescimento dos filhotes do grupo DP frente aos C é apenas momentâneo, já que a partir do $21^{\circ}$ ou $22^{\circ}$ dia de vida pós-natal torna-se impossível detectar diferenças entre os dois grupos (Gama e Alvares, 2000; Lin et al., 1998, 2001). Lima et al. (2011) revelaram que ratos desmamados precocemente apresentaram maior massa corpórea aos 180 dias de vida quando comparados a animais amamentados e, além deste sobrepeso, outros inúmeros fatores foram modificados pela interrupção da amamentação, compondo um quadro de desenvolvimento de síndrome metabólica. Desse modo, embora haja a recuperação de massa corpórea a partir do $18^{\circ}$ dia de vida, provavelmente algum mecanismo regulatório sensível ao desmame precoce foi reprogramado neste período e poderia se refletir na vida adulta.

A administração do antagonista do receptor GHS-R, [D-Lys-3]-GHRP-6 aos animais submetidos ao DP não influenciou a massa corpórea. Asakawa et al. (2003) mostraram que camundongos que receberam esta droga apresentaram redução significativa no consumo alimentar já a partir de 20 min após a injeção, mesmo tendo sido mantidos em jejum de $16 \mathrm{~h}$ previamente ao tratamento. Esta resposta se sustentou por um período de $4 \mathrm{~h}$, de maneira dose-dependente. Já os camundongos que tinham livre acesso à alimentação, mas receberam uma dose de ghrelina associada à dose do antagonista, também diminuíram o consumo alimentar a partir de 20 min das injeções e esse antagonismo persistiu por ao menos $1 \mathrm{~h}$.

Como não avaliamos o consumo alimentar dos filhotes, não podemos discutir se houve ou não modificação deste parâmetro a partir dos resultados obtidos para massa corpórea. Entretanto, o fato das injeções de antagonista terem sido aplicadas após o fornecimento individual de pasta de ração aos animais (por pipeta descartável) pode ter colaborado no sentido de não encontrarmos variação da massa corpórea final entre os grupos DP e DPA. Outro ponto que deve ser considerado é o intervalo entre o tratamento com o antagonista $\left(17^{\circ}\right.$ dia de vida pós-natal) e a coleta dos estômagos ( $18^{\circ}$ dia $)$, que representa um período curto para que os possíveis efeitos em termos de massa corpórea pudessem ser evidenciados. Devemos ressaltar que em nossos experimentos iniciais, foram realizadas tentativas de mensurar o consumo alimentar por meio da diferença de peso entre a ração oferecida e a restante na gaiola no dia subsequente. Entretanto, a metodologia utilizada mostrou-se falha ao detectarmos que o peso final da pasta de ração consumida durante o período de um dia era maior que o peso inicial. Este episódio pode ser atribuído à hidratação da pasta de ração 
provocada pela própria umidade da gaiola e do ambiente. Além disso, não encontramos uma forma segura de medir o consumo de leite pelo grupo C. Mesmo assim, consideramos diferentes possibilidades para a obtenção da medida do consumo alimentar como, por exemplo, o uso de gaiolas metabólicas, que foi descartado porque poderia estressar ainda mais os animais por permanecerem alojados individualmente.

Sabendo-se que o desmame precoce acelera o crescimento e que a ghrelina é um hormônio orexigênico (Cummings et al., 2001; Nakazato et al., 2001; Tschöp et al., 2000), que poderia estar envolvido nesse mecanismo, avaliamos sua distribuição e concentração na mucosa gástrica e estudamos como o desmame precoce poderia interferir em sua expressão.

Observamos que houve um aumento do número de células imunomarcadas para ghrelina aos 16 dias de vida pós-natal nos animais $\mathrm{C}$, que confirma o que já foi descrito por Björkqvist et al.(2002) e Lee et al. (2002). Entretanto, isso não ocorreu no grupo DP e a maior densidade de células foi encontrada somente aos 18 dias. Os resultados obtidos para a avaliação de ghrelina por meio da técnica de immunoblot confirmaram esse perfil, entretanto, não observamos o pico detectado por imuno-histoquímica no $16^{\circ}$ dia para os animais $\mathrm{C}$ e nem uma diferença tão expressiva entre C e DP no $18^{\circ}$ dia com o immunoblot. Isto poderia ser explicado levando-se em conta as diferenças de significado de cada técnica: enquanto a imuno-histoquímica identifica célula a célula e nos fornece o tamanho da população imunomarcada, o immunoblot nos revela os níveis de ghrelina na mucosa gástrica. Logo, é possível que haja um maior número de células secretando ghrelina sem que haja necessariamente uma elevação dos níveis hormonais, pois um aumento da população poderia significar justamente uma compensação da redução da síntese individual.

Em relação à ontogenia, sabe-se que a ghrelina é encontrada no estômago do rato ainda em idade fetal, em torno de 18 dias gestacionais, embora ainda em pequenas quantidades, que aumentam progressivamente até atingir valores compatíveis com a idade adulta, entre a terceira e a quinta semanas de vida pós-natal (Björkqvist et al., 2002; Chanoine e Wong, 2004; Chanoine et al., 2006; Hayashida et al., 2002; Lee et al., 2002). Entretanto, durante os períodos fetal e peri-natal, o pâncreas se destaca como fonte de ghrelina, e, simultaneamente ao aumento da síntese gástrica pós-natal, ocorre o decréscimo da síntese pancreática, que é quase indetectável na época do desmame (Chanoine e Wong, 2004; Chanoine et al., 2006, 2009; Walia et al., 2009).

Tendo em vista estas informações, outra possibilidade para a relação entre a população celular responsável pela síntese de ghrelina e sua concentração tecidual, seria a de que o aumento de células "X/A-like" somente se refletiria em níveis gástricos mais altos após 
determinado período de tempo, no $19^{\circ}$ ou $20^{\circ}$ dias pós-natais, por exemplo. Resultados de um estudo realizado previamente em nosso laboratório revelaram que o número de células imunomarcadas para ghrelina no estômago praticamente dobra do $14^{\circ}$ para o $30^{\circ}$ dia de vida e é paralelamente acompanhado por um aumento similar na concentração plasmática deste hormônio (Kasai et al., 2011). Björkqvist et al. (2002) também observaram uma ampliação semelhante na população de células que sintetizam ghrelina e o aumento correspondente na concentração sérica entre a segunda e a quarta semanas de vida pós-natal, com a subsequente estabilização. Consequentemente, a fase de desmame é um período crítico em relação à ontogenia da ghrelina e a condição de desmame precoce poderia representar um fator de adiantamento de uma característica observada apenas em uma idade mais avançada nos ratos.

Como já abordado anteriormente, a ghrelina também está sujeita aos efeitos de alterações no padrão alimentar, como o desmame tardio, por exemplo (Fåk et al., 2007). Nishi et al. (2005b) mostraram que ratos desmamados precocemente no $18^{\circ}$ dia de vida pós-natal apresentaram aumento nos níveis gástricos de ghrelina no $21^{\circ}$ dia. No nosso estudo, os filhotes foram submetidos ao desmame precoce no $15^{\circ}$ dia de vida e tiveram a população de células "X/A-like" e os níveis gástricos de ghrelina monitorados pelos 3 dias subsequentes. A primeira alteração promovida nos animais DP foi a diminuição tanto do número de células responsáveis pela síntese de ghrelina quanto dos níveis teciduais deste hormônio frente ao C, detectada nos dias 16 e 17 e, somente após esta resposta inicial, houve o aumento destes parâmetros no grupo DP, no $18^{\circ}$ dia de vida pós-natal.

Embora os modelos utilizados para o desmame precoce sejam distintos, visto que nosso último dia de tratamento representa o primeiro dia no trabalho de Nishi et al. (2005b), a resposta final foi semelhante. Desse modo, os resultados sugerem que a síntese de ghrelina é influenciada também pelo desmame precoce, além do desmame tardio (Fåk et al., 2007) e que, embora não saibamos quais mecanismos modulam esta resposta diferenciada frente à alteração de padrão alimentar, ela parece precisar de um período para se estabelecer.

No que concerne ao receptor GHS-R, utilizando a técnica de RT-PCR encontramos um perfil muito similar à variação observada para a ghrelina, embora as alterações detectadas não tenham sido estatisticamente significantes. Assim, quando comparados aos animais $\mathrm{C}$, os DP apresentaram menor expressão no $16^{\circ}$ e $17^{\circ}$ dias de vida pós-natal e o inverso ocorreu no $18^{\circ}$ dia, quando notamos um sutil aumento de RNAm para o GHS-R. A partir destes resultados, podemos inferir que a expressão de $G H S-R$ na mucosa gástrica durante o período estudado acompanhou a ocorrência da ghrelina. Entretanto, no intuito de avaliar o quanto deste RNAm era de fato convertido para a proteína GHS-R, utilizamos o immunoblot e, até 
conseguirmos padronizar uma reação reprodutível para a detecção do receptor, diversos protocolos foram testados.

Mesmo antes da ghrelina ser estabelecida como o ligante endógeno do GHS-R, alguns estudos já procuravam identificar a distribuição deste receptor, visto que ele estava envolvido na regulação da liberação de GH através do uso dos GHS (Akman et al., 1993; Cheng et al., 1989; Howard et al., 1996). No estudo de Guan et al. (1997) foi realizado um mapeamento do $G H S-R$ em ratos e humanos e os resultados apontaram a detecção do RNAm predominantemente no cérebro de ambas as espécies, e a ausência do mesmo em diversos órgãos, inclusive no estômago. Então, Shuto et al. (2001) desenvolveram um anticorpo para a detecção do GHS-R e conseguiram localizá-lo pela técnica de Western blot em extratos de hipotálamo, hipófise e estômago de rato, com bandas extremamente fracas para estes dois últimos órgãos. Como alguns tecidos que sabidamente expressavam GHS-R não apresentaram resultados positivos com o uso do anticorpo, Shuto et al. (2001) sugeriram que isso estaria associado aos baixos níveis de proteína nestes outros tecidos.

Gnanapavan et al. (2002) mapearam tecidos humanos e encontraram RNAm para GHS-Rla, o subtipo funcional do GHS-R, apenas na hipófise, tireoide, pâncreas, baço, coração e glândula adrenal, enquanto inúmeros outros órgãos, incluindo o estômago, não se mostraram responsivos. Em outro estudo com tecidos humanos, Ueberberg et al. (2009) reportaram que a expressão proteica da ghrelina foi detectada em apenas um terço das amostras positivas para o RNAm de ghrelina, o que também ocorreu em relação ao GHS-R1a, que não foi localizado no estômago, onde o RNAm para o receptor estava presente. McGirr et al. (2011) obtiveram respostas negativas para a presença do receptor GHS-R1a em estômago de camundongo por meio da técnica de Western blot, embora os extratos de coração e cérebro tenham respondido positivamente, sendo que o coração revelou bandas bastante intensas.

Considerando o exposto acima, fica evidente a dificuldade em localizar o receptor GHS-R, principalmente no que se refere à presença da proteína em si no extrato de diversos tecidos que conhecidamente a expressam. Então, inicialmente procuramos abordar o receptor GHS-R1a e inúmeras tentativas foram feitas até que conseguíssemos o resultado mostrado na Figura 7B, obtido com um carregamento de proteína total de $60 \mu \mathrm{g}$ e após 60 h de exposição ao anticorpo primário. Porém, mesmo com outras adaptações nos protocolos experimentais, não conseguimos reproduzir este resultado e uma nova abordagem foi utilizada, com outro anticorpo e uma extração proteica diferenciada, que permitisse o isolamento da membrana plasmática, já que o GHS-R é um receptor do tipo GPCR (Howard et al., 1996). 
Com base nas alterações que detectamos para a ghrelina aos 18 dias de vida pós-natal, a extração de proteínas de membrana foi realizada no material coletado de animais com esta mesma idade, para que pudéssemos verificar se o aumento do número de células que sintetizam ghrelina refletiria em uma elevação nos níveis de GHS-R, e o resultado encontrado mostrou-se compatível com o do RT-PCR: uma elevação não significativa estatisticamente nos níveis proteicos do receptor no grupo DP frente ao C. Portanto, o tratamento não interferiu com os níveis de GHS-R nas idades investigadas, contudo, seria importante estudar a expressão do receptor nos dias subsequentes, para avaliar se esta tendência levaria a um aumento real.

A ação da ghrelina no que se refere à sua atividade orexigênica se dá nos âmbitos central e periférico, já que diferentes vias de administração, como i.p., subcutânea (s.c.) ou intracérebroventricular (i.c.v.), foram utilizadas nos experimentos que resultaram em aumento de consumo alimentar e ganho de peso e mostraram-se responsivas. Assim, o efeito sobre o controle de apetite e ingestão alimentar da ghrelina é mediado por células que expressam os potentes orexígenos NPY (neuropeptídeo Y) e AGRP (agouti-related peptide), presentes no núcleo arqueado do hipotálamo e por receptores localizados nos neurônios aferentes do nervo vago (Asakawa et al., 2003; Nakazato et al., 2001; Shintani et al., 2001; Tschöp et al., 2000; Wren et al., 2000). Dessa forma, o fato do GHS-R não ter sofrido alterações no estômago nos nossos estudos não limita a resposta do organismo à ghrelina em termos de efeitos orexigênicos.

Em relação ao desenvolvimento gástrico, um estudo de Alvares e Gama (1993) mostrou que durante as três primeiras semanas de vida pós-natal, os ratos apresentam células proliferativas por toda a glândula e, somente após este período, estas células se concentram na região do istmo, já assumindo uma distribuição de acordo com o padrão encontrado nos animais adultos. Assim, em filhotes de 18 dias pós-natais, o compartimento proliferativo ainda não está completamente definido, ocupando toda a extensão da glândula gástrica. Sabese que o desmame precoce interfere na resposta proliferativa tanto do intestino delgado quanto do estômago: no primeiro, a região do jejuno mostra aumento expressivo de proliferação no $18^{\circ}$ dia (Lin et al., 1998), enquanto que no estômago, além deste aumento observado também no $18^{\circ}$ dia, ocorre a definição antecipada do compartimento proliferativo na região do istmo, como se o tratamento adiantasse o surgimento desta característica dos animais adultos (Gama e Alvares, 2000; Osaki et al., 2011). Estes achados reforçam o papel do leite materno como modulador do desenvolvimento funcional do epitélio do estômago e sugerem que a presença do leite no estômago, assim como de seus peptídeos biologicamente ativos, é extremamente 
importante para o crescimento adequado da mucosa gástrica (De Andrade Sá et al., 2008; Gama e Alvares, 2000; Lin et al., 2001; Ogias et al., 2010; Osaki et al., 2010, 2011).

Nossos resultados mostraram que a grande maioria das células em fase de síntese de DNA e, portanto, imunomarcadas pela BrdU, está concentrada no compartimento proliferativo, revelando que o tratamento com o antagonista [D-Lys-3]-GHRP-6 não interferiu na distribuição das células proliferativas no estômago dos animais desmamados precocemente. O uso do antagonista em duas doses de $5 \mu \mathrm{g} / \mathrm{g}$ de massa corpórea (DPA - [5]) promoveu uma diminuição significativa do IS, o que não foi observado com duas doses de 10 $\mu \mathrm{g} / \mathrm{g}$ de massa corpórea (DPA - [10]). Ao contrário, o grupo DPA - [10] apresentou IS muito similar ao encontrado para os animais DP. Uma possível explicação para este fato seria a saturação dos receptores GHS-R com uma dose excessiva de antagonista [D-Lys-3]-GHRP-6, o que acarretaria a ausência de resposta.

Como já mencionado anteriormente, informações relativas à farmacologia do antagonista do receptor GHS-R, [D-Lys-3]-GHRP-6, são extremamente escassas. A partir de seu uso nos estudos de Kojima et al. (1999) e Asakawa et al. (2003), nos quais se comprovou sua eficácia contra as ações clássicas da ghrelina, esta droga vem sendo largamente utilizada, embora características básicas como meia-vida, depuração e principais órgãos alvo não sejam conhecidas. Desse modo, a definição dos parâmetros para o tratamento com [D-Lys-3]GHRP-6 foi feita com base nos próprios estudos que o utilizaram, principalmente o trabalho de Asakawa et al. (2003), que mostraram que a dose de $200 \mathrm{nmol}$ (ponto de partida para nossos experimentos) resultou na supressão da ingestão alimentar.

Kasai et al. (2011) demonstraram que animais alimentados com uma dieta normocalórica hipoproteica apresentaram alteração do compartimento proliferativo, com a dispersão das células em divisão ao longo da glândula gástrica em detrimento de sua regionalização na região do istmo. Além disso, a restrição proteica diminuiu consideravelmente o IS em animais de 14, 30 e 50 dias de vida e, paralelamente, houve aumento dos níveis séricos de ghrelina, assim como do número de células imunomarcadas para este hormônio em animais com 30 e 50 dias de vida. Dessa forma, somente nos animais jovens e adultos, observa-se a inibição de proliferação celular concomitante ao aumento dos níveis de ghrelina.

A restrição proteica nos estudos de Kasai et al. (2011) também provocou diminuição da massa corpórea dos ratos e do peso do estômago, redução do comprimento intestinal e aumento expressivo do consumo alimentar medido em intervalos que cobrem do $22^{\circ}$ ao $50^{\circ}$ dia. Talvez a condição de restrição de proteínas represente uma situação de tamanho impacto 
para o organismo, visto o comprometimento do crescimento padrão de alguns órgãos, que o aumento dos níveis de ghrelina seja uma tentativa do organismo sinalizar a necessidade de maior quantidade de alimento para suprir o déficit proteico. O baixo IS poderia representar uma estratégia do organismo para preservar a funcionalidade dos órgãos, mesmo com taxas de crescimento comprometidas, frente à carência de proteínas.

Em contrapartida, no desmame precoce a proliferação celular na mucosa gástrica está aumentada aos 18 dias de vida pós-natal, quando comparada a animais amamentados normalmente (Gama e Alvares, 2000; Osaki et al., 2011). Cabe ressaltar que este estímulo não persiste aos 22 dias, quando não se observa variação na divisão celular do epitélio gástrico entre os grupos C e DP (Gama e Alvares, 2000). Ao estudarmos os níveis de ghrelina na mucosa do estômago durante a terceira semana de vida pós-natal, demonstramos que filhotes desmamados precocemente apresentaram uma elevação significativa da população de células "X/A-like" do $17^{\circ}$ para o $18^{\circ}$ dia, como mencionado anteriormente. Assim, durante o período de aumento deste hormônio, ocorreria um estímulo proliferativo, considerando-se a resposta gástrica clássica para o desmame precoce em termos de proliferação epitelial. Ao utilizarmos o antagonista [D-Lys-3]-GHRP-6 no $17^{\circ}$ dia de vida pós-natal, interferimos na resposta à ghrelina e observamos uma diminuição do IS em consequência do bloqueio do receptor GHSR no grupo DPA - [5]. Nesse contexto, podemos distinguir a relação da ghrelina com a proliferação celular entre animais na fase de desenvolvimento e na vida adulta, submetidos a diferentes padrões de alimentação.

A investigação das ações da ghrelina por mecanismo autócrino / parácrino é restrita e, tem se mostrado associada à proliferação maligna em alguns tipos de tumores (De Vriese e Delporte, 2007; Jeffery et al., 2003; Nikolopoulos et al., 2010; Waseem et al., 2008), portanto é necessário que se ampliem os estudos que avaliam a participação da ghrelina propriamente dentro da cinética celular, considerando um efeito parácrino não relacionado à malignidade. 


\section{CONCLUSÕES}

Diante dos nossos resultados, podemos constatar que:

1) A condição de desmame precoce altera o número de células secretoras de ghrelina na mucosa gástrica, porém não interfere na sua distribuição na glândula e esta variação foi concomitante, ou até mesmo precedida, pelo aumento de massa corpórea;

2) O receptor GHS-R está presente epitélio do estômago pelo menos desde o $15^{\circ}$ dia de vida pós-natal;

3) O GHS-R gástrico não sofre modificações advindas do desmame precoce;

4) A inibição da ghrelina resulta em diminuição do índice de síntese de DNA na mucosa gástrica dos filhotes submetidos ao desmame precoce.

Com base nestes resultados, podemos sugerir que os níveis de ghrelina na mucosa gástrica são afetados por mudanças no padrão de dieta e que a ghrelina parece participar do controle proliferativo do epitélio do estômago, devendo ser considerada um importante elemento no complexo mecanismo regulatório do crescimento gástrico durante a transição alimentar representada pelo desmame. 


\section{REFERÊNCIAS $^{1}$}

Ackerman SH, Hofer MA, Weiner H. Predisposition to gastric erosions in the rat: behavioral and nutritional effects of early maternal separation. Gastroenterology. 1978;75(4):649-54.

Aherne WA, Camplejohn RS, Wright NA. An introduction to population cell kinetics. London: Edward Arnold; 1977.

Akman MS, Girard M, O’Brien LF, Ho AK, Chik CL. Mechanisms of action of a second generation growth hormone-releasing peptide (Ala-His-D-betaNal-Ala-Trp-D-Phe-Lys- $\mathrm{NH}_{2}$ ) in rat anterior pituitary cells. Endocrinology. 1993;132(3)1286-91.

Alvares EP. The effect of fasting on cell proliferation in the gastric mucosa of the 14-day old suckling rat. Braz J Med Biol Res. 1992;25(6):641-9.

Alvares EP. Extensive networks of TMPase positive basal lysosomes are present in fetal rat gastric epithelium before overt differentiation. J Submicrosc Cytol Pathol. 1994;26(4):515-23.

Alvares EP, Gama P. Fasting enhances cell proliferation of gastric epithelium during the suckling period in rats. Braz J Med Biol Res. 1993;26(8):869-73.

Alvares EP, Jordão LR, Gama P. Differential distribution of transforming growth factor beta and receptors in the hyper or hypoproliferative gastric mucosa of developing and adult rats. Histol Histopathol. 2007;22(2):147-53.

Asakawa A, Inui A, Kaga T, Katsuura G, Fujimiya M, Fujino MA, Kasuga M. Antagonism of ghrelin receptor reduces food intake and body weight gain in mice. Gut. 2003;52(7):947-52.

Baldanzi G, Filigheddu N, Cutrupi S, Catapano F, Bonissoni S, Fubini A, Malan D, Baj G, Granata R, Broglio F, Papotti M, Surico N, Bussolino F, Isgaard J, Deghenghi R, Sinigaglia F, Prat M, Muccioli G, Ghigo E, Graziani A. Ghrelin and des-acyl ghrelin inhibit cell death in cardiomyocytes and endothelial cells through ERK1/2 and PI 3-kinase/AKT. J Cell Biol. 2002;159(6):1029-37.

Banks WA, Tschöp M, Robinson SM, Heiman ML. Extent and direction of ghrelin transport across the blood-brain barrier is determined by its unique primary structure. $\mathrm{J}$ Pharmacol Exp Ther. 2002;302(2):822-7.

Blake AD, Smith RG. Desensitization studies using perifused rat pituitary cells show that growth hormone-releasing hormone and His-D-Trp-Ala-Trp-D-Phe-Lys- $\mathrm{NH}_{2}$ stimulate growth hormone release through distinct receptor sites. J Endocrinol. 1991;129(1):11-9.

Beck B, Richy S, Stricker-Krongrad A. Feeding response to ghrelin agonist and antagonist in lean and obese Zucker rats. Life Sci. 2004;76(4):473-8.

\footnotetext{
${ }^{1}$ De acordo com: International Committee of Medical Journal Editors. Uniform requirements for manuscripts submitted to Biomedical Journal: sample references. Available from: $<$ http://www.nlm.nih.gov/bsd/uniform_requirements.html> [2007 May 22].
} 
Björkqvist M, Dornonville de la Cour C, Zhao CM, Gagnemo-Persson R, Håkanson R, Norlén P. Role of gastrin in the development of gastric mucosa, ECL cells and A-like cells in newborn and young rats. Regul Pept. 2002;108(2-3):73-82.

Boyle JT, Koldovský O. Critical role of adrenal glands in precocious increase in jejunal sucrose activity following premature weaning in rats: negligible effect of food intake. J Nutr. 1980;110(1):169-77.

Bowers CY, Momany FA, Reynolds GA, Hong A. On the in vitro and in vivo activity of a new synthetic hexapeptide that acts on the pituitary to specifically release growth hormone. Endocrinology. 1984;114(5):1537-45.

Bradford MM. A rapid and sensitive method for the quantitation of microgram quantities of protein utilizing the principle of protein-dye binding. Anal Biochem. 1976;72:248-54.

Brasil. Ministério da Saúde. Secretaria de Atenção à Saúde. Departamento de Ações Programáticas e Estratégicas. II Pesquisa de prevalência de aleitamento materno nas capitais brasileiras e Distrito Federal. Brasília: Ministério da Saúde; 2009. Disponível em: $<$ http://bvsms.saude.gov.br/bvs/publicacoes/pesquisa_prevalencia_aleitamento_materno.pdf $>$. [2012 abr. 19].

Brittan M, Wright NA. The gastrointestinal stem cell. Cell Prolif. 2004;37(1):35-53.

Camiña JP. Cell biology of the ghrelin receptor. J Neuroendocrinol. 2006;18(1):65-76.

Chanoine JP, Wong AC. Ghrelin gene expression is markedly higher in fetal pancreas compared with fetal stomach: effect of maternal fasting. Endocrinology. 2004;145(8):381320 .

Chanoine JP, Wong AC, Barrios V. Obestatin, acylated and total ghrelin concentrations in the perinatal rat pancreas. Horm Res. 2006;66(2):81-8.

Chanoine JP, De Waele K, Walia P. Ghrelin and the growth hormone secretagogue receptor in growth and development. Int J Obes (Lond). 2009;33 Suppl 1:S48-52.

Cheng K, Chan WW, Barreto A Jr, Convey EM, Smith RG. The synergistic effects of His-DTrp-Ala-Trp-D-Phe-Lys- $\mathrm{NH}_{2}$ on growth hormone $(\mathrm{GH})$-releasing factor - stimulated $\mathrm{GH}$ release and intracellular adenosine $3^{\prime}, 5^{\prime}$-monophosphate accumulation in rat primary pituitary cell culture. Endocrinology. 1989;124(6):2791-8.

Cheng K, Chan WW, Butler B, Barreto A Jr, Smith RG. Evidence for a role of protein kinase$\mathrm{C}$ in His-D-Trp-Ala-Trp-D-Phe-Lys- $\mathrm{NH}_{2}$-induced growth hormone release from rat primary pituitary cells. Endocrinology. 1991;129(6):3337-42.

Chung H, Kim E, Lee DH, Seo S, Ju S, Lee D, Kim H, Park S. Ghrelin inhibits apoptosis in hypothalamic neuronal cells during oxygen-glucose deprivation. Endocrinology. 2007;148(1):148-59.

Cripps RL, Martin-Gronert MS, Ozanne SE. Fetal and perinatal programming of appetite. Clin Sci (Lond). 2005;109(1):1-11. 
Cummings DE, Purnell JQ, Frayo RS, Schmidova K, Wisse BE, Weigle DS. A preprandial rise in plasma ghrelin levels suggests a role in meal initiation in humans. Diabetes. 2001;50(8):1714-9.

Dass NB, Munonyara M, Bassil AK, Hervieu GJ, Osbourne S, Corcoran S, Morgan M, Sanger GJ. Growth hormone secretagogue receptors in rat and human gastrointestinal tract and the effects of ghrelin. Neuroscience. 2003;120(2):443-53.

Date Y, Kojima M, Hosoda H, Sawaguchi A, Mondal MS, Suganuma T, Matsukura S, Kangawa K, Nakazato M. Ghrelin, a novel growth hormone-releasing acylated peptide, is synthesized in a distinct endocrine cell type in the gastrointestinal tracts of rats and humans. Endocrinology. 2000a;141(11):4255-61.

Date Y, Murakami N, Kojima M, Kuroiwa T, Matsukura S, Kangawa K, Nakazato M. Central effects of a novel acylated peptide, ghrelin, on growth hormone release in rats. Biochem Biophys Res Commun. 2000b;275(2):477-80.

Date Y, Nakazato M, Murakami N, Kojima M, Kangawa K, Matsukura S. Ghrelin acts in the central nervous system to stimulate gastric acid secretion. Biochem Biophys Res Commun. 2001;280(3):904-7.

Date Y, Nakazato M, Hashiguchi S, Dezaki K, Mondal MS, Hosoda H, Kojima M, Kangawa K, Arima T, Matsuo H, Yada T, Matsukura S. Ghrelin is present in pancreatic alpha-cells of humans and rats and stimulates insulin secretion. Diabetes. 2002;51(1):124-9.

De Andrade Sá ER, Bitencourt B, Alvares EP, Gama P. In vivo effects of TGFbeta1 on the growth of gastric epithelium in suckling rats. Regul Pept. 2008;146(1-3):293-302.

De Vriese C, Delporte C. Autocrine proliferative effect of ghrelin on leukemic HL-60 and THP-1 cells. J Endocrinol. 2007;192(1):199-205.

Donovan SM, Odle J. Growth factors in milk as mediators of infant development. Annu Rev Nutr. 1994;14:147-67.

Ekelund M, Hakanson R, Hedenbro J, Rehfeld JF, Sundler F. Endocrine cells and parietal cells in the stomach of the developing rat. Acta Physiol Scand. 1985;124(4):483-97.

Fåk F, Friis-Hansen L, Weström B, Wierup N. Gastric ghrelin cell development is hampered and plasma ghrelin is reduced by delayed weaning in rats. J Endocrinol. 2007;192(2):345-52.

Figueiredo PM. Papel da interação entre padrão alimentar, corticosterona e fatores de crescimento na regulação da proliferação celular no epitélio gástrico de ratos em desenvolvimento pós-natal. [dissertação (Mestrado em Biologia Celular e Tecidual)]. São Paulo: Instituto de Ciências Biomédicas, Universidade de São Paulo; 2010.

Fukushima N, Hanada R, Teranishi H, Fukue Y, Tachibana T, Ishikawa H, Takeda S, Takeuchi Y, Fukumoto S, Kangawa K, Nagata K, Kojima M. Ghrelin directly regulates bone formation. J Bone Miner Res. 2005;20(5)790:8. 
Gama P, Alvares EP. LHRH and somatostatin effects on the cell proliferation of the gastric epithelium in suckling and weaning rats. Regul Pept. 1996;63(2-3):73-8.

Gama P, Alvares EP. Early weaning and prolonged nursing induce changes in cell proliferation in the gastric epithelium of developing rats. J Nutr. 2000;130(10):2594-8.

Glavin GB, Pare WP. Early weaning predisposes rats to exacerbated activity-stress ulcer formation. Physiol Behav. 1985;34(6):907-9.

Gnanapavan S, Kola B, Bustin SA, Morris DG, McGee P, Fairclough P, Bhattacharya S, Carpenter R, Grossman AB, Korbonits M. The tissue distribution of the mRNA of ghrelin and subtypes of its receptor, GHS-R, in humans. J Clin Endocrinol Metab. 2002;87(6):2988-91.

Gutierrez JA, Solenberg PJ, Perkins DR, Willency JA, Knierman MD, Jin Z, Witcher DR, Luo S, Onyia JE, Hale JE. Ghrelin octanoylation mediated by an orphan lipid transferase. Proc Natl Acad Sci U S A. 2008;105(17):6320-5.

Guan XM, Yu H, Palyha OC, McKee KK, Feighner SD, Sirinathsinghji DJ, Smith RG, Van der Ploeg LH, Howard AD. Distribution of mRNA encoding the growth hormone secretagogue receptor in brain and peripheral tissues. Brain Res Mol Brain Res. 1997;48(1):23-9.

Harder T, Bergmann R, Kallischnigg G, Plagemann A. Duration of breastfeeding and risk of overweight: a meta-analysis. Am J Epidemiol. 2005;162(5):397-403.

Hayashida T, Nakahara K, Mondal MS, Date Y, Nakazato M, Kojima M, Kangawa K, Murakami N. Ghrelin in neonatal rats: distribution in stomach and its possible role. J Endocrinol. 2002;173(2):239-45.

Helander HF. The cells of the gastric mucosa. Int Rev Cytol. 1981;70:217-89.

Henning SJ. Postnatal development: coordination of feeding, digestion and metabolism. Am J Physiol. 1981;241(3):G199-214.

Horta BL, Bahl R, Martines JC, Victora CG. Evidence on the long-term effects of breastfeeding: systematic review and meta-analyses. Geneva: WHO Press; 2007. Available from: <http://whqlibdoc.who.int/publications/2007/9789241595230_eng.pdf>. [2012 Apr 19].

Hosoda H, Kojima M, Matsuo H, Kangawa K. Ghrelin and des-acyl ghrelin: two major forms of rat ghrelin peptide in gastrointestinal tissue. Biochem Biophys Res Commun. 2000a;279(3):909-13.

Hosoda H, Kojima M, Matsuo H, Kangawa K. Purification and characterization of rat desGln14-Ghrelin, a second endogenous ligand for the growth hormone secretagogue receptor. J Biol Chem. 2000b;275(29):21995-2000.

Howard AD, Feighner SD, Cully DF, Arena JP, Liberator PA, Rosenblum CI, Hamelin M, Hreniuk DL, Palyha OC, Anderson J, Paress PS, Diaz C, Chou M, Liu KK, McKee KK, Pong SS, Chaung LY, Elbrecht A, Dashkevicz M, Heavens R, Rigby M, Sirinathsinghji DJ, Dean DC, Melillo DG, Patchett AA, Nargund R, Griffin PR, DeMartino JA, Gupta SK, Schaeffer 
JM, Smith RG, Van der Ploeg LH. A receptor in pituitary and hypothalamus that functions in growth hormone release. Science. 1996;273(5277):974-7.

Inui A. Ghrelin: an orexigenic and somatotrophic signal from the stomach. Nat Rev Neurosci. 2001;2(8):551-60.

Jeffery PL, Herington AC, Chopin LK. The potential autocrine/paracrine roles of ghrelin and its receptor in hormone-dependent cancer. Cytokine Growth Factor Rev. 2003;14(2):113-22.

Johnson LR. Functional development of the stomach. Annu Rev Physiol. 1985;47:199-215.

Karam SM. Dynamics of epithelial cells in the corpus of the mouse stomach. IV. Bidirectional migration of parietal cells ending in their gradual degeneration and loss. Anat Rec. $1993 ; 236(2): 314-32$.

Karam SM, Leblond CP. Dynamics of epithelial cells in the corpus of the mouse stomach. I. Identification of proliferative cell types and pinpointing of the stem cell. Anat Rec. 1993a;236(2):259-79.

Karam SM, Leblond CP. Dynamics of epithelial cells in the corpus of the mouse stomach. II. Outward migration of pit cells. Anat Rec. 1993b;236(2):280-96.

Karam SM, Leblond CP. Dynamics of epithelial cells in the corpus of the mouse stomach. III. Inward migration of neck cells followed by progressive transformation into zymogenic cells. Anat Rec. 1993c;236(2):297-313.

Karam SF, Leblond CP. Dynamics of epithelial cells in the corpus of the mouse stomach. V. Behavior of entero-endocrine and caveolated cells: general conclusions on cell kinetics in the oxyntic epithelium. Anat Rec. 1993d;236(2):333-40.

Karam SM. Cell lineage relationship in the stomach of normal and genetically manipulated mice. Braz J Med Biol Res. 1998;31(2):271-9.

Karam SM. Lineage commitment and maturation of epithelial cells in the gut. Front Biosci. 1999;4:D286-98.

Kasai A, Gama P, Alvares EP. Protein restriction inhibits gastric cell proliferation during rat postnatal growth in parallel to ghrelin changes. Nutrition. 2011 Dec 30. Available from: <http://dx.doi.org/10.1016/j.nut.2011.10.003>. [2012 Apr 19].

Keeley TM, Samuelson LC. Cytodifferentiation of the postnatal mouse stomach in normal and Huntingtin-interacting protein 1-related-deficient mice. Am J Physiol Gastrointest Liver Physiol. 2010;299(6):G1241-51.

Kikusui T, Mori Y. Behavioural and neurochemical consequences of early weaning in rodents. J Neuroendocrinol. 2009;21(4):427-31.

Kitazawa T, De Smet B, Verbeke K, Depoortere I, Peeters TL. Gastric motor effects of peptide and non-peptide ghrelin agonist in mice in vivo and in vitro. Gut. 2005;54(8):1078-84. 
Kojima M, Hosoda H, Date Y, Nakazato M, Matsuo H, Kangawa K. Ghrelin is a growthhormone-releasing acylated peptide from stomach. Nature. 1999;402(6762):656-60.

Kojima M, Kangawa K. Ghrelin: structure and function. Physiol Rev. 2005;85(2):495-522.

Koldovský O. Response of the gastrointestinal tract to premature weaning in experimental animals. Pediatrics 1985;75(1 Pt 2):199-206.

Koldovský O. Search for role of milk-borne biologically active peptides for the suckling. J Nutr. 1989;119(11):1543-51.

Koldovský O, Illnerová H, Macho L, Strbák V, Stĕpánková R. Milk-borne hormones: possible tools of communication between mother and suckling. Physiol Res. 1995;44(6):34951.

Lall S, Tung LY, Ohlsson C, Jansson JO, Dickson SL. Growth hormone (GH)-independent stimulation of adiposity by $\mathrm{GH}$ secretagogues. Biochem Biophys Res Commun. 2001;280(1):132-8.

Lee ER, Trasler J, Dwivedi S, Leblond CP. Division of the mouse gastric mucosa into zymogenic and mucous regions on the basis of gland features. Am J Anat. 1982;164(3):187207.

Lee HM, Wang G, Englander EW, Kojima M, Greeley GH Jr. Ghrelin, a new gastrointestinal endocrine peptide that stimulates insulin secretion: enteric distribution, ontogeny, influence of endocrine, and dietary manipulations. Endocrinology. 2002;143(1):185-90.

Lee PC, Lebenthal E. Early weanling and precocious development of small intestine in rats: genetic, dietary or hormonal control. Pediatr Res. 1983;17(8):645-50.

Lima N da S, de Moura EG, Passos MC, Nogueira Neto FJ, Reis AM, de Oliveira E, Lisboa PC. Early weaning causes undernutrition for a short period and programmes some metabolic syndrome components and leptin resistance in adult rat offspring. $\mathrm{Br} \mathrm{J}$ Nutr. 2011;105(9):1405-13.

Lin CH, Correia L, Tolia K, Gesell MS, Tolia V, Lee PC, Luk GD. Early weaning induces jejunal ornithine decarboxylase and cell proliferation in neonatal rats. $\mathrm{J}$ Nutr. 1998;128(10):1636-42.

Lin $\mathrm{CH}$, Lyons $\mathrm{H}$, Seelbach MS, Tolia V, Vijesurier R. Induction of gastric ornithine decarboxylase in early weaning rats. Digestion. 2001;63(4):214-9.

Masuda Y, Tanaka T, Inomata N, Ohnuma N, Tanaka S, Itoh Z, Hosoda H, Kojima M, Kangawa K. Ghrelin stimulates gastric acid secretion and motility in rats. Biochem Biophys Res Commun. 2000;276(3):905-8.

McGirr R, McFarland MS, McTavish J, Luyt LG, Dhanvantari S. Design and characterization of a fluorescent ghrelin analog for imaging the growth hormone secretagogue receptor $1 \mathrm{a}$. Regul Pept. 2011;172(1-3)69-76. 
McKee KK, Palyha OC, Feighner SD, Hreniuk DL, Tan CP, Phillips MS, Smith RG, Van der Ploeg LH, Howard AD. Molecular analysis of rat pituitary and hypothalamic growth hormone secretagogue receptors. Mol Endocrinol. 1997;11(4):415:23.

Momany FA, Bowers CY, Reynolds GA, Hong A, Newlander K. Conformational energy studies and in vitro and in vivo activity data on growth hormone-releasing peptides. Endocrinology. 1984;114(5):1531-6.

Nakazato M, Murakami N, Date Y, Kojima M, Matsuo H, Kangawa K, Matsukura S. A role for ghrelin in the central regulation of feeding. Nature. 2001;409(6817):194-8.

Nanthakumar NN, Young C, Ko JS, Meng D, Chen J, Buie T, Walker WA. Glucocorticoid responsiveness in developing human intestine: possible role in prevention of necrotizing enterocolitis. Am J Physiol Gastrointest Liver Physiol. 2005;288(1):G85-92.

Nikolopoulos D, Theocharis S, Kouraklis G. Ghrelin: a potential therapeutic target for cancer. Regul Pept. 2010;163(1-3):7-17.

Nishi Y, Hiejima H, Hosoda H, Kaiya H, Mori K, Fukue Y, Yanase T, Nawata H, Kangawa $\mathrm{K}$, Kojima M. Ingested medium-chain fatty acids are directly utilized for the acyl modification of ghrelin. Endocrinology. 2005a;146(5):2255-64.

Nishi Y, Hiejima H, Mifune H, Sato T, Kangawa K, Kojima M. Developmental changes in the pattern of ghrelin's acyl modification and the levels of acyl-modified ghrelins in murine stomach. Endocrinology. 2005b;146(6):2709-15.

Ogias D, de Andrade Sá ER, Alvares EP, Gama P. Opposite effects of fasting on TGF-beta3 and TbetaRI distribution in the gastric mucosa of suckling and early weanling rats. Nutrition. 2010;26(2):224-9.

Osaki LH, Curi MA, Alvares EP, Gama P. Early weaning accelerates the differentiation of mucous neck cells in rat gastric mucosa: possible role of TGFalpha/EGFR. Differentiation. 2010;79(1):48-56.

Osaki LH, Figueiredo PM, Alvares EP, Gama P. EGFR is involved in control of gastric cell proliferation through activation of MAPK and Src signalling pathways in early-weaned rats. Cell Prolif. 2011;44(2):174-82.

Park JM, Kakimoto T, Kuroki T, Shiraishi R, Fujise T, Iwakiri R, Fujimoto K. Suppression of intestinal mucosal apoptosis by ghrelin in fasting rats. Exp Biol Med (Maywood). 2008;233(1):48-56.

Penttila IA, van Spriel AB, Zhang MF, Xian CJ, Steeb CB, Cummins AG, Zola H, Read LC. Transforming growth factor-beta levels in maternal milk and expression in postnatal rat duodenum and ileum. Pediatr Res. 1998;44(4):524-31.

Romero A, Kirchner H, Heppner K, Pfluger PT, Tschöp, MH, Nogueiras R. GOAT: the master switch for the ghrelin system? Eur J Endocrinol. 2010;163(1):1-8. 
Rozen S, Skaletsky HJ. Primer 3. 1998. Available from: $<$ http://www.broadinstitute.org/genome_software/other/primer3.html>. [2012 Apr 19].

Sakata I, Nakamura K, Yamazaki M, Matsubara M, Hayashi Y, Kangawa K, Sakai T. Ghrelin-producing cells exists as two types of cells, closed- and opened-type cells, in the rat gastrointestinal tract. Peptides. 2002;23(3):531-6.

Sakata I, Yang J, Lee CE, Osborne-Lawrence S, Rovinsky SA, Elmguist JK, Zigman JM. Colocalization of ghrelin $O$-acyltransferase and ghrelin in gastric mucosal cells. Am J Physiol Endocrinol Metab. 2009;297(1):E134-41.

Sánchez J, Oliver P, Picó C, Palou A. Diurnal rhythms of leptin and ghrelin in the systemic circulation and in the gastric mucosa are related to food intake in rats. Pflugers Arch. 2004;448(5):500-6.

Sato T, Fukue Y, Teranishi H, Yoshida Y, Kojima M. Molecular forms of hypothalamic ghrelin and its regulation by fasting and 2-deoxy-D-glucose administration. Endocrinology. 2005;146(6):2510-6.

Sato T, Nakamura Y, Shiimura Y, Ohgusu H, Kangawa K, Kojima M. Structure, regulation and function of ghrelin. J Biochem. 2012;151(2):119-28.

Shintani M, Ogawa Y, Ebihara K, Aizawa-Abe M, Miyanaga F, Takaya K, Hayashi T, Inoue G, Hosoda K, Kojima M, Kangawa K, Nakao K. Ghrelin, an endogenous growth hormone secretagogue, is a novel orexigenic peptide that antagonizes leptin action through the activation of hypothalamic neuropeptide Y/Y1 receptor pathway. Diabetes. 2001;50(2):22732 .

Shuto Y, Shibasaki T, Wada K, Parhar I, Kamegai J, Sugihara H, Oikawa S, Wakabayashi I. Generation of polyclonal antiserum against the growth hormone secretagogue receptor (GHSR): evidence that the GHS-R exists in the hypothalamus, pituitary and stomach of rats. Life Sci. 2001;68(9):991-6.

Smith SS, Ojeda SR. Maternal modulation of infantile ovarian development and available ovarian luteinizing hormone-releasing hormone (LHRH) receptors via milk LHRH. Endocrinology. 1984;115(5):1973-83.

Stengel A, Goebel M, Wang L, Taché Y, Sachs G, Lambrecht NW. Differential distribution of ghrelin- $O$-acyltransferase (GOAT) immunoreactive cells in the mouse and rat gastric oxyntic mucosa. Biochem Biophys Res Commun. 2010;392(1):67-71.

Tannenbaum GS, Lapointe M, Beaudet A, Howard AD. Expression of growth hormone secretagogue-receptors by growth hormone-releasing hormone neurons in the mediobasal hypothalamus. Endocrinology. 1998;139(10):4420-3.

Tschöp M, Smiley DL, Heiman ML. Ghrelin induces adiposity in rodents. Nature. 2000;407(6806):908-13.

Ueberberg B, Unger N, Saeger W, Mann K, Petersenn S. Expression of ghrelin and its receptor in human tissues. Horm Metab Res. 2009;41(11):814-21. 
Walia P, Asadi A, Kieffer TJ, Johnson JD, Chanoine JP. Ontogeny of ghrelin, obestatin, preproghrelin, and prohormone convertases in rat pancreas and stomach. Pediatr Res. 2009;65(1):39-44.

Waseem T, Javaid-Ur-Rehman, Ahmad F, Azam M, Qureshi MA. Role of ghrelin axis in colorectal cancer: a novel association. Peptides. 2008;29(8):1369-76.

World Health Organization. Global strategy for infant and young child feeding. The optimal duration of exclusive breastfeeding. Fifty-fourth World Health Assembly - A54/INF.DOC./4. 2001. Available from: <http://apps.who.int/gb/archive/pdf_files/WHA54/ea54id4.pdf>. [2012 Apr 19].

World Health Organization. Infant and young child nutrition. Global strategy on infant and young child feeding. Fifty-fifth World Health Assembly - A55/15. 2002. Available from: $<$ http://apps.who.int/gb/archive/pdf_files/WHA55/ea5515.pdf>. [2012 Apr 19].

Wren AM, Small CJ, Ward HL, Murphy KG, Dakin CL, Taheri S, Kennedy AR, Roberts GH, Morgan DG, Ghatei MA, Bloom SR. The novel hypothalamic peptide ghrelin stimulates food intake and growth hormone secretion. Endocrinology. 2000;141(11):4325-8.

Xin Z, Serby MD, Zhao H, Kosogof C, Szczepankiewicz BG, Liu M, Liu B, Hutchins CW, Sarris KA, Hoff ED, Falls HD, Lin CW, Ogiela CA, Collins CA, Brune ME, Bush EN, Droz BA, Fey TA, Knourek-Segel VE, Shapiro R, Jacobson PB, Beno DWA, Turner TM, Sham HL, Liu G. Discovery and pharmacological evaluation of growth hormone secretagogue receptor antagonists. J Med Chem. 2006;49(15):4459-69.

$\mathrm{Xu}$ RJ. Development of the newborn GI tract and its relation to colostrum/milk intake: a review. Reprod Fertil Dev. 1996;8(1):35-48.

Yang J, Brown MS, Liang G, Grishin NV, Goldstein JL. Identification of the acyltransferase that octanoylates ghrelin, an appetite-stimulating peptide hormone. Cell. 2008;132(3):387-96.

Young CM, Lee PC, Lebenthal E. Maternal dietary restriction during pregnancy and lactation: effect on digestive organ development in suckling rats. Am J Clin Nutr. 1987;46(1):36-40.

Zhang JV, Ren PG, Avsian-Kretchmer O, Luo CW, Rauch R, Klein C, Hsueh AJ. Obestatin, a peptide encoded by the ghrelin gene, opposes ghrelin's effects on food intake. Science. 2005;310(5750):996-9.

Zhu X, Cao Y, Voogd K, Steiner DF. On the processing of proghrelin to ghrelin. J Biol Chem. 2006;281(50):38867-70. 